
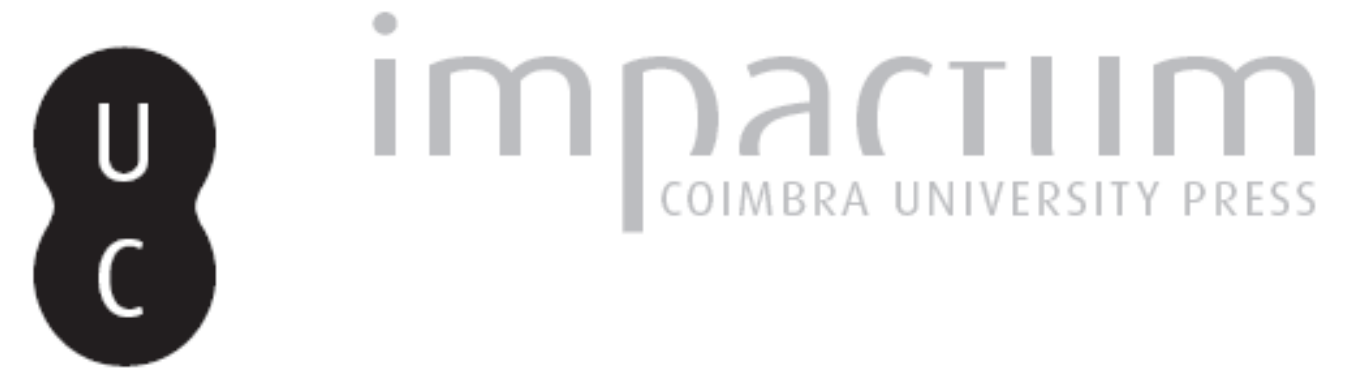

\title{
A arqueologia e o tempo
}

\section{Autor(es): $\quad$ Alarcão, Jorge de}

Publicado por: Imprensa da Universidade de Coimbra

URL persistente:

URI:http://hdl.handle.net/10316.2/45475

DOI:

DOI:https://dx.doi.org/10.14195/1647-8657_32_33_1

Accessed : $\quad$ 26-Apr-2023 00:11:26

A navegação consulta e descarregamento dos títulos inseridos nas Bibliotecas Digitais UC Digitalis, UC Pombalina e UC Impactum, pressupõem a aceitação plena e sem reservas dos Termos e Condições de Uso destas Bibliotecas Digitais, disponíveis em https://digitalis.uc.pt/pt-pt/termos.

Conforme exposto nos referidos Termos e Condições de Uso, o descarregamento de títulos de acesso restrito requer uma licença válida de autorização devendo o utilizador aceder ao(s) documento(s) a partir de um endereço de IP da instituição detentora da supramencionada licença.

Ao utilizador é apenas permitido o descarregamento para uso pessoal, pelo que o emprego do(s) título(s) descarregado(s) para outro fim, designadamente comercial, carece de autorização do respetivo autor ou editor da obra.

Na medida em que todas as obras da UC Digitalis se encontram protegidas pelo Código do Direito de Autor e Direitos Conexos e demais legislação aplicável, toda a cópia, parcial ou total, deste documento, nos casos em que é legalmente admitida, deverá conter ou fazer-se acompanhar por este aviso.

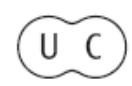




\section{UNIVERSIDADE DE COIMBRA \\ FACULDADE DE LETRAS}

\section{CONIMBRIGA}

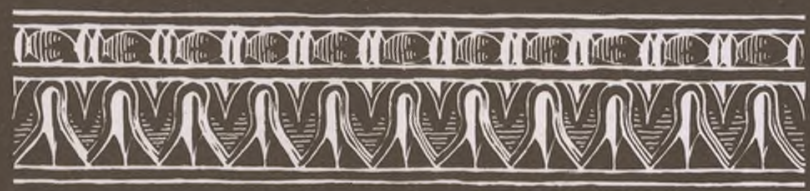

VOLUMES XXXII-XXXIII-1993/94 


\title{
JORGE DE ALARCão
}

Professor da Faculdade de Letras de Coimbra

\author{
A ARQUEOLOGIA E O TEMPO \\ «Conimbriga» XXXII-XXXIII (1993-1994), p. 9-56
}

RESUMO: Os tempos são múltiplos porque a realidade social tem vários planos: as estruturas económicas e sociais evoluem mais lentamente do que as acções políticas, que se desenrolam num tempo breve. Mas, num outro sentido, os tempos são múltiplos porque as sociedades primitivas têm uma visão predominantemente cíclica do tempo, enquanto as sociedades mais avançadas tem uma visão mais linear, unidireccional.

Estuda-se o tempo das coisas, das acções, das normas, dos aparelhos e das paisagens. Coisas e acções vêm do futuro para o passado, enquanto normas, aparelhos e paisagens vêm do passado para o presente.

Analisa-se a duração (objectiva ou subjectiva) e devir das coisas; apresenta-se uma breve teoria da acção; discute-se, a propósito das normas, o conceito de habitus de Bourdieu; examinam-se as condições de possibilidade do devir dos aparelhos e analisa-se a percepção do espaço como algo de construível.

Distinguem-se depois os conceitos de duração, sucessão e processo e examina-se se o tempo linear é uma intuição transcendental de que o arqueólogo não pode deixar de fazer uso, ou, como pretendem Shanks e Tilley, uma construção capitalista. Por fim, contrastam-se o tempo linear e o tempo cíclico.

SUMMARY: The subject of this paper concerns the perspective of time. Social reality has several levels, each of them with its own rhythm: economic structures move slowly, while historical actions occur in Braudel's short time-scale. Time too has several levels: primitive people conceive of a cyclical or recurrent time; more developed societies feel that time flows continuously in a single direction.

Conimbriga, 32-33 (1993-1994), 9-56 
The time spectrum of artifacts, actions, rules, political institutions and landscapes are successively examined. Artifacts and actions take shape in the future, to flow into the present, and disappear into the past. Rules and political institutions on the other hand come to the present from the past.

The rise and duration (objective or subjective) of artifacts are considered; a brief theory of action is presented; Bourdieu's notion of habitus is reconsidered and the conditions under which a change in political institutions may be possible is discussed. The emergence of the perception that the landscape may be altered or reconstructed is dated to the Neolithic.

Concepts of duration, succession and process are explored. Linear time is considered as a transcendental intuition and not as a creation of modem capitalism, as proposed by Shanks and Tilley.

Finally, the paper contrasts cyclical against linear time. 


\section{A ARQUEOLOGIA E O TEMPO}

\section{Introdução}

A multiplicidade dos tempos é um tema em que insistem arqueólogos, historiadores e sociólogos. "Não há um tempo único, mas, pelo contrário, muitos "tempos" diferentes que são representados de muitas maneiras distintas" (BAILLEY, 1983: 168).

A multiplicidade dos tempos tem pelo menos dois sentidos. Num primeiro, os tempos são múltiplos porque a realidade social, o facto social total, para usar a expressão de Marcel Mauss, tem várias camadas. Nesse sentido, Braudel $(1983 ; 1984)$ distingue o meio, que evolui muito lentamente, das estruturas económicas e sociais, que evoluem a outro ritmo, mas ainda lentas, das acções políticas, que se sucedem num tempo breve. Distingue, assim, longa e breve duração. O conceito de longa duração foi assimilado pela Arqueologia e Hodder, por exemplo, editou uma obra intitulada Archaeology as long-term history (1987).

Gurvitch (1979: 83) afirma que "a realidade social apresenta-se ao olhar experimentado do sociólogo como disposta em patamares, em níveis, em planos sobrepostos, em camadas cada vez mais profundas. Estes níveis, estes planos sobrepostos, interpenetram-se e impregnam-se mutuamente. No entanto, não deixam de entrar em conflito: as suas relações são tensas, antinómicas, dialécticas". E distingue (GURVITCH, 1986: 385 s.) oito géneros de tempos sociais: "o tempo de longa duração e ao retardador, o tempo de ilusão, o tempo descompassado entre o aparecimento e o desaparecimento dos ritmos, o tempo cíclico, o tempo atrasado em relação a si próprio, o tempo de alternância entre atraso e avanço, o tempo adiantado em relação a si próprio e o tempo explosivo". Os diferentes géneros de tempo são depois equacionados com os diversos níveis em profundidade da realidade social. 
Num outro sentido, afirma-se que a representação do tempo é culturalmente específica, isto é, que várias sociedades têm vários conceitos do tempo (FERRAROTTI, 1990: 9, 67) e contrastam-se a visão linear das sociedades evoluídas e a visão cíclica das sociedades primitivas e rurais, ou a visão unidireccional do Cristianismo com o eterno retomo do pensamento mítico.

Bailey (1983: 170) parece reagir contra a concepção de um tempo linear, unidireccional, representado como um espaço em que nós posicionamos os acontecimentos. Shanks e Tilley (1983: 118-136) contestam, inequivocamente, tal concepção. Mas nenhum dos autores apresenta, afinal, uma concepção alternativa do tempo que deva ser adoptada pelos arqueólogos. Bailey desvia-se para uma discussão dos ritmos evolutivos, que são diferentes consoante consideramos o plano do biológico, o do ambiental e o do social: a evolução é mais lenta no primeiro, menos lenta no segundo e mais rápida no último. Prossegue com uma análise da causalidade, mostrando que as causas actuantes no plano dos factos de longa duração não são as mesmas que determinam a evolução dos factos de duração breve, o que é óbvio. Reinterpretando, numa nomenclatura escolástica, a posição de Bailey, diríamos que as causas ambientais são causae efficientes, enquanto os factos sociais se explicam por causae finales. Em conclusão: Bailey não demonstra que o tempo linear é inapropriado ao exame da realidade histórica que o arqueólogo se propõe observar, mas simplesmente fundamenta a necessidade de distinguirmos, nessa realidade, diversos planos cuja evolução tem ritmos diferentes: uns mais lentos, outros mais rápidos.

Mais radicais, Shanks e Tilley pretendem que a concepção linear do tempo não permite entender devidamente a realidade social do passado. Influenciados por Dilthey, através de Colling wood (The idea of history), assumem a posição de que, para entender o passado, nos temos de colocar na perspectiva do outro, do homem do passado e de raciocinar com as concepções do tempo que tinham esses homens do passado. Ainda que não claramente afirmada, há uma ideia que subjaz ao pensamento destes autores: que a ideia do tempo é derivada da percepção fenomenologica da sucessão. "O tempo não existe numa forma abstracta e sem conteúdo" (1993: 127). O que existe é um tempo substantivo, um tempo preenchido de factos. Se os homens experimentam os factos como irrepetíveis, formam uma concepção linear; se os vivem como repetíveis a espaços regulares, uma concepção cíclica. Estas di-

Conimbriga, 32-33 (1993-1994), 9-56 
ferentes concepções do tempo "conformam a propria história" (SHANKS e TILLEY, 1993: 127), isto é, a visão unilinear fomenta o progresso, e a visão cíclica, o tradicionalismo. A visão cíclica coexiste com uma memória social curta; a visão linear, com uma memória mais longa e, sobretudo, com a ideia de que o futuro é calculável, qualquer coisa que não repete o passado, que pode ser diferente do passado e que pode ser feita por nós à medida dos nossos desejos.

Apesar do valioso contributo que estas reflexões trouxeram, parece-nos necessário aprofundar certas análises. $\mathrm{O}$ mundo tem uma estrutura que pretendemos examinar. Se a experiência "é a presença imediata e directa do que se nos apresenta" (MüLLER, 1959: 13), como é que o mundo se apresenta a quem vive nele? Como é que se apresentam coisas, acções, normas, aparelhos e paisagens?

Analisaremos, depois, os conceitos de sucessão e processo; discutiremos se o tempo linear é, como pretendem Shanks e Tilley, uma construção capitalista; e, finalmente, equacionaremos o tempo cíclico e o tempo linear com os ritmos da mudança.

\section{O tempo das coisas}

A Arqueologia, em primeiro lugar, trata de coisas: deste machado, desta foice, deste monumento megalítico, desta cabana que, para além de ser ela mesma uma coisa, é ainda lugar onde se encontram outras coisas, coisa imóvel que abrigou uma familia, a qual deixou, no chão, utensílios ou destroços de utensilios de que se serviu. A Arqueologia não se limita ao estudo da cultura material, mas parte necessariamente da cultura material.

As coisas não têm, como o homem, um passado, um presente e um futuro. É certo que esta coisa de que me sirvo neste momento (o cinzeiro onde descanso o cigarro) já aí estava, à espera de que eu me servisse dela; e vou ainda servir-me dela no futuro. Mas a coisa de que me servi, me sirvo e me servirei, parece não ter devir; ela é sempre a mesma coisa, sempre este cinzeiro, sempre esta caneta, coisa idêntica a ela mesma. Só metaforicamente posso dizer que a coisa estava ali, à espera de que eu me servisse dela, porque as coisas não podem esperar nada. As coisas não têm futuro: apenas podem estar aí ainda no meu futuro. E também não têm passado, embora possam ser coisas do passado, isto é, feitas por homens que me antecederam.

Conimbriga, 32-33 (1993-1994), 9-56 
A coisa tem, todavia, uma duração: foi feita agora, vai ser utilizada durante algum tempo e, por fim, deixará de servir. O deixar de servir (que HeIDEGGER examinou em Etre et temps, § 16) não é deixar de ser nem de existir: este machado de pedra polida, que foi usado até ao ponto déjà não servir, foi atirado para uma lixeira; mas não deixou por isso de existir nem de ser machado; só que deixou de servir. Este leque que eu tenho na minha colecção de antiguidades já não serve; mas não deixou de existir nem de ser leque; existe como leque, só que já sem a sua serventia original. Há uma diferença, porém, entre o objecto que já não serve mas conservo e o objecto que atiro para uma lixeira: o primeiro permanece no meu mundo, embora inútil (ou destituído da sua utilidade original); o segundo sai do meu mundo, deixa de ser objecto de percepção, podendo todavia, ainda durante algum tempo, ser recordado.

Sou eu que decreto o fim da serventia ou que decido quando é que o objecto sai do meu mundo (excepto no caso dos objectos perdidos, que saem do meu mundo contra minha vontade). Foi esta população neolítica que determinou deixar de usar este monumento megalítico para enterrar os seus mortos e deliberou construir um monumento novo. Mas o antigo monumento não deixou de existir: ele continuou ali na paisagem e só teria desaparecido se a população tivesse decidido destruí-lo, transportando os esteios para outro lugar. Mesmo assim, o monumento continuaria a existir durante algum tempo, só que sob o modo de recordação.

Se o homem decreta o fim da serventia do objecto (ou do monumento), o decreto não é gratuito: este camponês neolítico só deixava de servir-se do machado, declarando-o inútil ou sem préstimo, quando o machado estava fisicamente gasto em demasia e já não era eficiente. Quer dizer que há, afinal, e ao contrário do que acima nos parecia, um devir do objecto, que se vai fazendo inútil; metaforicamente podemos dizer que se vai fazendo velho.

O envelhecimento das coisas, que não é, evidentemente, um processo biológico como o dos seres vivos, não é a única forma de devir das coisas. Primeiro, porque passar de útil a inútil, que é a primeira forma do devir, não é necessariamente um resultado do envelhecimento. $\mathrm{O}$ objecto pode deixar de ser utilizado antes de atingir o limiar de ineficiência. Estes objectos que encontro nesta sepultura foram aí enterrados (e, portanto, subtraídos à utilização) quando ainda estavam em condições de servir, quando eram novos. Mas há, para a coisa, outra forma

Conimbriga, 32-33 (1993-1994), 9-56 
de devir sem ser por envelhecimento ou pela subtracção à utilização. $\mathrm{O}$ monumento de Stonehenge, por exemplo, foi remodelado por diversas vezes, e não terá sido por se achar velho. Ou, para dar outro exemplo, este povoado castrejo sofreu uma evolução, estendeu-se ou contraiu-se, foi defendido por novas muralhas, construiram-se nele novas casas. Temos aqui também um devir, uma história que tem de ser reconstituída. O devir das coisas não é apenas passagem de útil a inútil, mas também alteração da forma. Alteração que pode manter a qualidade da coisa. Stonehenge e o castro não deixaram de ser o que eram. Noutros casos, porém, a alteração da forma corresponde à alteração do ser, como no caso desta peça de sílice que, partida, foi reaproveitada, retocada e transformada noutro objecto com outra utilidade.

Não é a coisa que se vai fazendo velha por si mesma ou que se vai transformando por si própria; é o homem quem, utilizando o objecto, o vai fazendo velho e finalmente o torna inútil; é o homem que vai transformando, isto é, dando nova forma à coisa. Esta não pode operar a sua própria velhice ou a sua metamorfose. A coisa não é responsável pelo seu devir. Mas será o homem o único responsável pelo devir da coisa? Se não existe processo biológico de degradação das coisas, existe um processo físico, como o desta casa que se vai degradando até ruir, ou o desta cabana que o vento pode destroçar. O homem não é, pois, o único responsável pela velhice e pelo devir das coisas. O senso comum faz, do Tempo e da Natureza, agentes do envelhecimento e do devir da coisa. Para evitar a hipóstase do Tempo, que repugnará a uma consciência filosófica, podemos recorrer ao conceito de durabilidade da coisa, durabilidade parcialmente condicionada pelo uso que é feito dessa mesma coisa, pois que uma panela muito usada dura menos que uma panela raramente utilizada. Mas a hipóstase da Natureza parece difícil de evitar: mesmo que esta cabana resista menos a um temporal por ser mais frágil, o agente da destruição não é a fragilidade da cabana, mas o temporal.

As coisas têm, pois, um tempo de vida, uma duração; e, enquanto duram, podem não se manter idênticas a elas mesmas, podem ir sendo transformadas. As coisas têm uma duração e um devir.

Que podemos deduzir desta reflexão, que seja relevante para a prática arqueológica? Podemos deduzir que se devem formular perguntas sobre a duração e o devir das coisas: quando é que foram feitas ou fabricadas? quando é que deixaram de servir ou quando é que foram

Conimbriga, 32-33 (1993-1994), 9-56 
abandonadas? foram usadas durante quanto tempo? quando deixaram de servir eram novas ou velhas, isto é, no momento do abandono ou da inutilização eram coisas ainda prestáveis ou já sem serventia? sofreram, enquanto estiveram em uso, transformações?

Quando eu escavo este monumento megalítico, procuro identificar o paleossolo, isto é, o que era camada superficial do terreno na altura em que o monumento foi construído; e procuro recolher aí, ou eventualmente nalguma fogueira que possa relacionar com a fundação do megálito, alguns carvões susceptíveis de serem sujeitos à análise radiocarbónica, para determinar quando é que o megálito foi construído. Quando escavo uma villa romana, procuro determinar a cronologia das moedas ou das cerâmicas encontradas na camada de destruição para, através delas, determinar a cronologia do abandono. E se, relativamente a um mesmo monumento, conseguir determinar a data da fundação e a do abandono, terei a duração do monumento. Esta duração, balizada por datas de cronologia absoluta, é uma duração objectiva. Veremos já que é possível falar de uma duração subjectiva das coisas.

É, evidentemente, muito mais difícil datar o fabrico e o abandono de um utensílio do que a construção e abandono de um edifício. Por isso a pergunta não é geralmente formulada, embora, no caso dos vasos gregos, por exemplo, se consiga determinar a data de fabrico de peças individuais (quando atribuíveis a um pintor particular) e, no caso das moedas, a data da emissão. Relativamente aos utensílios, porém, o que o arqueólogo geralmente procura são as balizas cronológicas de um tipo e não a data dos objectos individuais: esta ânfora romana concreta integrale num tipo, por exemplo, Haltern 70, e nós podemos determinar quando é que o tipo foi inventado e quando é que deixou de fabricar-se.

Independentemente da duração objectiva do monumento ou do tipo, medida em anos, podemos determinar se este objecto foi utilizado até ao limite da sua eficácia ou se foi abandonado ou enterrado sendo todavia ainda novo.

A resposta à questão sobre se o objecto foi utilizado até ao limite da sua eficácia tem profundas implicações. Primeiro, porque dela depende aquilo que poderemos pensar relativamente à natureza do objecto. Se este escudo de bronze, que se encontrou nas águas do Tamisa, tem vestígios de ter sido usado durante algum tempo, poderemos dizer que ele foi objecto útil, com que se defendeu um guerreiro ou um chefe que terá eventualmente morrido afogado. Mas se o objecto está no- 
vo, sem sinais de uso, deveremos pensar que se trata de um objecto fabricado não para ser útil mas para ser votivo, isto é, para ser oferecido, logo depois de feito, a uma qualquer divindade residente nas águas do rio. Da observação dos traços de uso (ou da falta de uso) deduzimos uma função e através dela entramos, neste caso, num mundo de ideias, de crenças e de ritos.

Neste povoado neolítico ou calcolitico encontro numerosos machados de pedra polida. Estão eles usados ou novos? Se estão usados, deduziremos que serviram, que houve desflorestação intensiva e prática da agricultura. Se estão novos, posso admitir que eram acumulados como riqueza, para serem utilizados em transacções económicas ou sociais, isto é, para serem trocados por outras coisas ou para serem cedidos como preço ou dote das noivas, por exemplo.

A duração das coisas pode também ser significativa de factos económicos. Kristiansen (1984: 91-92) dividiu a Idade do Bronze dinamarquesa em seis períodos e observou que, nalguns, os objectos foram enterrados apenas quando já se encontravam gastos ou muito usados, enquanto outros foram depositados sendo ainda novos ou quase novos. Daqui deduziu que o abastecimento do bronze (que a Dinamarca não produzia e tinha de ser importado do Sul) sofreu flutuações: houve períodos de maior importação (e então os objectos eram depositados nos túmulos ou em oferendas aos deuses sendo ainda novos) e períodos de maior dificuldade no abastecimento (e nesses, os objectos foram conservados e usados durante mais tempo).

As coisas podem ter, porém, uma duração subjectiva: este filme, que durou hora e meia, pareceu-me longo, porque não gostei dele; este outro, que durou exactamente o mesmo tempo, pareceu-me breve porque me interessou profundamente. Também esta peça de cerâmica, de que gostava muito, pareceu-me ter durado pouco; e aquela, que durou o mesmo tempo antes de se partir, pareceu-me ter durado muito porque não gostava dela. A duração subjectiva da coisa não é recuperável pelo arqueólogo, porque isso implicaria o acesso àquilo que é, evidentemente, inacessível: o facto psicológico individual.

Da mesma forma, a velhice de um objecto pode ser objectiva ou subjectiva. Se o objecto está gasto de tanto uso que teve e serve já mal a sua função, está objectivamente velho. Mas se eu tenho um carro comprado há pouco, e portanto objectivamente novo, a saída de outro modelo faz-me sentir o carro como velho. Os habitantes dos castros 
construíram durante muitas gerações casas redondas de pedra cobertas de colmo ou giesta. Mas veio um dia em que alguns começaram a construir casas rectangulares cobertas de telha. O proprietário de uma casa redonda sentiu-se então dono de uma casa velha.

Aqui, a apreciação não foi um juízo objectivo, baseado na degradação física da casa, mas subjectivo. Nos tempos de mudança, o objectivamente novo pode parecer velho. Mas é difícil ao arqueólogo, se não mesmo impossível, perceber se o novo pareceu velho a quem se serviu das coisas. Mais uma vez, isso entra no campo dos factos psicológicos individuais inacessíveis.

As coisas podem, pois, tornar-se velhas não por se terem degradado mas por ter surgido um modelo ou estilo novo. A emergência de um estilo novo das coisas, mesmo que torne velho o estilo até então adoptado, não significa, porém, que o velho seja abandonado e depreciado. Os períodos em que velho e novo coexistem, em que formas tradicionais, de longa duração, se acham a par de formas novas, são particularmente interessantes para o arqueólogo, porque permitem abordar relações sociais e mentalidades.

Temos, em Pompeia, quatro estilos de pintura mural que se sucedem. O advento do segundo tornou o primeiro, velho. Que significado poderá ter o facto de um proprietário ter decorado a sua casa no primeiro estilo quando outros contemporâneos adoptavam já o segundo? Conservadorismo? Desejo de representar simbolicamente a antiguidade da família? E os que adoptavam o novo faziam-no por mero gosto estético ou para demonstrar espírito aberto à novidade? Terá o segundo estilo, o novo, sido adoptado primeiramente por alguns proprietários desejosos de se distinguirem socialmente? Em que medida é que os estilos da pintura mural pompeiana serviram estratégias de poder pessoal, de uns que queriam afirmar-se pela prosápia, contra outros que procuravam impôr-se pela modernidade e pela diferença?

Tomemos, ainda como exemplo da dialéctica entre o novo e o velho (ou, talvez melhor, o tradicional, o que tem um passado), o caso da introdução do vaso campaniforme na planície de Salisbury (Inglaterra), nos inícios do segundo milénio a. C. Nesse momento, havia aí um importante monumento religioso do tipo henge: Durrington Walls. Neste se celebravam rituais acompanhados de banquetes largamente participados que usavam grandes vasos cerâmicos integráveis num tipo que os arqueólogos chamam Grooved ware. Provavelmente, os banquetes eram oferecidos por um chefe que seria o oficiante das cerimónias ri-

Conimbriga, 32-33 (1993-1994), 9-56 
tuais e cujo poder se fundaria exactamente na função religiosa. Esse chefe e os seus descendentes não adoptaram a nova cerâmica campaniforme, que, só muito depois de ter sido introduzida na região, aparece em Durrington Walls. Mas a cerâmica campaniforme não era uma cerâmica comum: era uma cerâmica de prestígio, adoptada por outros chefes. O facto de ela não aparecer em Durrington Walls parece significar, não só que os chefes "titulares" do monumento não adoptaram o estilo novo, como também que excluíram os outros chefes de frequentarem o henge e as suas cerimónias. Talvez seja significativo o facto de, neste momento do aparecimento da cerâmica campaniforme na planície de Salisbury, o henge de Durrington Walls ter sido circundado por um fosso e um talude que, simbolicamente, poderão ter restringido o acesso ao monumento e às cerimónias que aí se desenrolavam. A manutenção do estilo antigo de cerâmica e a não adopção do novo estilo campaniforme poderão ainda ter sido um modo de manifestar a antiguidade de um poder que também se fundava nessa mesma antiguidade e se legitimava por ela (THOMAS, 1991: 150-151).

A duração objectiva das coisas pode assim ser, nalguns casos, analisada pelo arqueólogo; a duração subjectiva, nunca. As transformações que a coisa (muralha de castro, villa romana, etc.) sofreu, transformações que constituem o seu devir, podem eventualmente ser datadas. Se as transformações foram introduzidas porque a coisa estava objetivamente velha, ou apenas porque era subjectivamente percebida como velha, é mais difícil de determinar. Se a coisa foi abandonada ou subtraída à utilização sendo objectivamente velha ou nova é ainda, em muitos casos, determinável.

\section{O tempo das acções}

Toda a coisa, cuja duração e devir acabámos de examinar, pressupõe ou implica uma acção. Em primeiro lugar, uma acção que a fabrica ou pela qual a coisa advém à existência; em segundo lugar, uma acção que a utiliza e que, por isso, é responsável pela duração da coisa, na medida em que uma utilização intensiva abrevia o momento do abandono e uma utilização menos frequente adia o momento em que a coisa é declarada já sem préstimo e abandonada; finalmente, uma acção que transforma a coisa ou pode transformá-la e que, por isso, lhe determina o devir.

Conimbriga, 32-33 (1993-1994), 9-56 
Nem toda a acção, porém, é criadora ou transformadora de coisas. Se a acção do oleiro cria o pote ou a de um ferreiro, uma lança, que coisa criaram os assassinos de Viriato? Um cadáver?

Não podemos prosseguir a nossa análise sem apresentarmos uma breve teoria da acção. Não nos interessa discutir o problema da liberdade ou do determinismo; interessa-nos, fundamentalmente, o que poderemos designar por taxinomia da acção, isto é, uma distinção dos diversos tipos de acção.

$\mathrm{O}$ latim distingue facere, de agere. $\mathrm{O}$ verbo agere, que se conserva no português agir e no francês agir, sofreu, no castelhano, um naufrágio, como sugestivamente lhe chama Jesus Mosterín (1987: 142): não existe em castelhano verbo que derive de agere', o verbo latino perdeu-se. Mas desse naufrágio salvou-se o participio passado, actum, que deu acto em castelhano. O desaparecimento, nesta língua, do agere poderia levar-nos à conclusão de que entre facere e agere existe total sinonimia: uma das formas, por redundante, teria desaparecido. Mas o castelhano criou actuar a par com hacer (dt facere), reintroduzindo a duplicidade vocabular. Se hacer e actuar, no castelhano, faire e agir, no francês, fazer e agir, no português, têm campos semânticos parcialmente coincidentes, os seus significados não se sobrepõem totalmente: a existência de dois verbos sugere que fazer e agir correspondem a dois tipos diferentes de acção.

Fazer, no sentido de fabricar (fazer uma panela, fazer uma lança), corresponde à acção que podemos designar por técnica. Nesta, o agente está confrontado com uma matéria à qual dá forma; matéria bruta, inanimada, destituída de intenções. O saber técnico, que é um saber como fazer as coisas, opõe-se ao saber hermenêutico, que é um saber àcerca dos homens, das suas intenções, dos seus desejos. A esse saber técnico deram os Gregos o nome de technê (embora o termo grego designasse simultaneamente o saber fazer dos artesãos e o dos artistas). Poderíamos também chamar-lhe saber mecânico, e acção mecânica à acção que lhe corresponde, à acção de fazer coisas. Recuperaríamos assim o sentido medieval de mecânico: os ofícios de oleiro, ferreiro, etc. eram ofícios mecânicos.

Nem os Gregos consideravam a actividade do lavrador como technê (VERNANT, 1971, II, 21), nem na Idade Média a agricultura estava incluída entre os ofícios mecânicos. Mas parece conveniente incluir a prática da agricultura entre as acções técnicas. A exploração da natureza, com vista à obtenção de meios de subsistência ou de matérias-pri-

Conimbriga, 32-33 (1993-1994), 9-56 
mas para fabricar coisas, releva ainda de um saber técnico. Poderíamos talvez distinguir a acção fabril, que consiste em fazer coisas, da acção exploratoria, que consiste em obter meios de subsistência ou matérias-primas.

Mas tomemos agora um texto de Díon Cássio, 37, 52-55: "E assim, embora lhe [a César] fosse possível permanecer em paz, conforme referi, dirigiu-se ao monte Herminio e ordenou aos habitantes que descessem à planície. Isto, dizia-o, para que eles não se lançassem em pilhagens utilizando como base as suas fortificações; mas, na realidade, sabia perfeitamente que eles jamais cumpririam esta ordem e poderia encontrar aí um pretexto de guerra. Assim aconteceu de facto. E quando alguns habitantes circunvizinhos, no temor de que também os viesse a atacar, puseram a salvo as suas mulheres e filhos e demais bens de valia através do Dório, ocupou-lhes as suas cidades enquanto eles nisto se afadigavam. Atacou-os em seguida. Os habitantes puseram o gado na sua frente com o intuito de caírem sobre os Romanos quando estes se dispersassem para capturar as reses, mas ele não se prendeu com os animais e atacou os homens, vencendo-os...".

A acção ou as acções aqui envolvidas são de uma natureza totalmente diferente: já não se trata de explorar a natureza ou de fabricar coisas, mas de agir sobre homens. E essa acção pressupõe uma previsão da acção dos outros, dos seus comportamentos, das suas reacções. César ordenou o abandono dos castros; mas imaginava que os indígenas não lhe obedeceriam, o que lhe daria pretexto a uma intervenção armada; especulou, pois, sobre as reacções dos adversários. Os habitantes do Herminio dispersaram os gados, na convicção ou na esperança de que os Romanos se dispersariam também para capturarem os animais; mas enganaram-se. Temos aqui, portanto, consciências que se espiam, se prevêem, se interpretam, acertando nuns casos, enganando-se noutros. Temos um saber que classificamos de hermenêutico e uma acção a que chamaremos social, porque envolve não as coisas, mas outros homens. A acção social corresponde a uma reciprocidade entre sujeitos, uma intersubjectividade, uma relação dialógica, uma conexão interactiva, enquanto a relação com a coisa ou a natureza é uma relação monológica. (Não podemos, todavia, ignorar que a relação com o outro pode ser também monológica, quando ele é tratado como coisa, sem reconhecimento do seu direito à liberdade e da sua capacidade de palavra).

Esta distinção entre acção técnica e acção social corresponde à que o jovem Hegel de lena estabeleceu entre dialéctica do trabalho e 
dialética da interacção (HABERMAS, 1993: 11-43; FERRY, 1987: 341-342).

A questão não é, talvez, tão simples: será monológica a relação dos primitivos com a Natureza, ou também dialógica, na medida em que a Natureza aparece povoada de espíritos? Se os espíritos, sobrenaturais, são dotados de intenções, teremos aqui uma outra forma de acção, afim da social, acção que podemos designar por mântica para a distinguirmos da acção entre os homens. Os meios que permitem agir sobre os seres sobrenaturais constituem os rituais, obedientes a normas diferentes das da aç̧ão técnica ou das normas éticas que regulamentam a acção social.

Qualquer que seja o tipo da acção (técnica, social ou mântica), esta implica uma intenção. Nada se faz sem intenção de se fazer. Poderíamos dizer que há aç̧ões involuntárias, realizadas sem intenção. Se eu acendo uma fogueira numa mata, apenas com intenção de assar castanhas, e se a fogueira pega fogo à mata, não sou eu o agente de uma acção involuntária, não intencional? $\mathrm{O}$ fogo da mata, assim provocado, não é, porém, uma acção, mas apenas uma consequência (não intencional) da acção, sem prejuízo da responsabilidade criminal que me poderá ser imputada. As acções (necessariamente intencionais) podem ser causa (involuntária, inadvertida, não intencional) de outros factos que todavia não são acções, mas consequências de acções.

Neste sentido de definir a intenção como característica da acção se pronuncia Mosterin (1987: 170-172). Também Isambert (1993: 118) diz que "o sentido da acção reside inteiramente no projecto, isto é, nesse futuro anterior que prepara a acção, a orienta e depois permite avaliar a realização" (itálicos do autor). É certo que outros autores assumem posição divergente e consideram que a intenção não é essencial à acção (v.g. White, 1976: 7-31). No fundo, a divergência é talvez apenas terminológica. As acções que vulgarmente se designam por involuntárias ou não intencionais devem, numa análise filosófica da acção, ser ainda consideradas como aç̧ões, ou meramente como consequências não intencionais da aç̧ão? Assumimos aqui a posição de considerar como acções apenas as que se realizam com intenção, excluindo, por conseguinte, do campo das acções, os movimentos reflexos do nosso corpo, como digerir, respirar ou espirrar.

O conceito de intenção é todavia um conceito elíptico, isto é, envolve ou integra outros conceitos menores ou componentes. Em primeiro lugar, o conceito de fim. Quando actuó, tenho um fim em vista. 
O fim é o motor da acção, essa causalidade invertida de que fala Sartre (1993: 145), porque, sendo fim, está no princípio. Os fins imediatos são meios para outros fins, e estes ainda meios para outros fins, não numa cadeia interminável, mas numa cadeia que se encerra naquilo que pode ser definido como fim último. Concebendo o fim, tenho de conceber também os meios para alcançá-lo. A concepção conjunta do fim e dos meios chamamos ideação da acção.

Ideada a acção, tenho de dispor-me a realizá-la; sem essa disposição não haverá acção. Há uma distância temporal entre a ideação e a realização da acção; eu posso realizar de imediato a acção ideada ou adiar a realização, ou mesmo nunca a realizar (por medo das consequências, por falta de possibilidade). Não há, por conseguinte, acção sem uma volição, sem uma decisão de realizar o fim concebido. Mas, ao contrário do que diz Prichard (1976: 95-96: a acção "é uma actividade que consiste na volição de uma mudança, volição que habitualmente causa essa mudança"), a acção não consiste na volição: esta é apenas um momento daquela. A volição pressupõe uma representação antecipada da acção. Na hesitação que podemos experimentar em realizar ou não a acção ideada temos a percepção da distância entre ideação e volição. Pressupondo uma ideação da acção, a volição tem por objecto a acção ideada e não a ideação da acção.

O uso, neste contexto, da palavra "volição" não pode entender-se no sentido de uma decisão inteiramente livre: eu posso deliberar agir por ser forçado a isso, quer o constrangimento provenha de outro(s), que me obriga(m) a agir contra meu desejo, quer provenha de mim mesmo, que me decido sem ter todavia desejo de fazê-lo.

Mas o que é o desejo? Que diferença existe entre desejo e volição? E qual é o objecto do desejo?

Platão, no Górgias (467d), define como objecto do desejo não a acção, mas aquilo que nós pretendemos quando realizamos a acção. Assim, faz da acção um meio para a realização de um fim último que ultrapassa a acção, que está fora dela. Nesta perspectiva, a morte de César seria o objecto do desejo de Bruto e dos conspiradores e o assassinato de César seria a acção, isto é, o meio para alcançar o fim desejado. Se bem que esta perspectiva seja defensável, preferimos abordar de outra forma o problema do objecto do desejo.

Quando realizo uma acção, nem sempre tenho garantia de que a acção se realize tal como a tinha ideado; pode sair, contra minha vontade, diferente da acção ideada. Aqui entra o desejo. O desejo é sempre

Conimbriga, 32-33 (1993-1994), 9-56 
desejo de algo: desejar é um verbo transitivo. Este algo que é objecto do desejo é que a acção feita coincida com a acção ideada ou que a acção feita não produza consequências que possam corresponder, do meu ponto de vista, a insucessos: desejo que a fogueira não pegue fogo à mata, desejo que o indivíduo contra quem disparo um tiro, morra (era esse o meu objectivo) e não fique simplesmente ferido.

Nesta perspectiva, o desejo é sempre desejo de que a acção seja bem sucedida. Mas não é verdade que pode também existir desejo de que a acção se não efectúe, como, por exemplo, quando decido submeter-me a uma operação cirúrgica que todavia não desejo? Assim, o desejo seria qualquer coisa como um modo de estar perante uma acção ideada, modo esse que conheceria graus entre os polos extremos do desejar que qualquer coisa se realize e o desejar que não se efectúe: posso desejar que sim ou não com maior ou menor intensidade.

O desejar que qualquer coisa se não efectúe é, todavia, uma aversão. Se fizermos uso deste conceito, podemos manter que o desejo tem sempre por objecto a acção ideada e é uma aspiração a que ela se realize como foi ideada ou até mais facilmente ou com maior êxito. Quando a acção ideada não desperta o nosso desejo, desperta a nossa aversão.

$\mathrm{Na}$ ordem lógica, a ideação vem primeiro, integrando concepção de um fim e concepção dos meios; depois, o desejo ou a aversão; em terceiro lugar, a volição, mais fácil se houver desejo, mais difícil se houver aversão; finalmente vem a execução.

Apresentada uma teoria da acção, que, no âmbito deste artigo, pode ter parecido longa mas que, na realidade, foi breve (quanto se não tem escrito sobre a teoria da acção!), podemos agora pôr o problema de saber se o arqueólogo pode aceder às acções.

As acções dos homens do passado não são directamente observáveis: eu não posso ver a trabalhar o grupo que construiu este megálito, o oleiro que fez este pote. Mas posso imaginar os homens agindo, como um investigador criminalista pode imaginar os gestos do criminoso e da vítima sem ter presenciado o crime.

Se a palavra imaginar tem sentidos múltiplos (DUFRENNE, 1953: 432-461), um desses sentidos é exactamente o de representar-se a acção sem a ter executado ou sem a ter observado como testemunha presencial. Podemos, a partir da escavação de um dolmen, imaginar um grupo limpando o terreno da vegetação, transportando sobre rolos as

Conimbriga, 32-33 (1993-1994), 9-56 
pedras que vão servir de esteios do megálito, erguendo primeiro o da cabeceira, instalando depois os outros, contrafortando os esteios, amontoando a terra da mamôa, cobrindo-a de uma couraça pétrea. A nossa representação não tem a riqueza da representação que teríamos no caso de termos sido testemunhas presenciais; é uma representação esquelética, em muitos pontos dubitativa. Mas não estamos condenados a ter apenas representação da coisa feita, do opus operatum; podemos representar-nos a coisa em trânsito, a coisa sendo feita, o opus operandi. E é exactamente esse conhecimento do opus operandi que nos permite repetir a acção, se estivermos interessados nisso. Normalmente não estamos; mas que é a Arqueologia experimental senão essa repetição das acções do passado?

Se "reconhecer um objecto útil consiste sobretudo em saber servir-se dele" (BERGSON, cit. por DUfRENNE, 1953: 430), imaginar a acção é poder reproduzi-la ou repeti-la tal como foi executada, é ter o saber necessário para erguer um dolmen ou fazer um pote como os homens do passado.

Para o conhecimento do opus operandi é importante a investigação etnoarqueológica: o estudo dos índios Yanomamo da Venezuela, que usam machados de pedra polida (CARNEIRO, 1979: 21-58), ajuda a conhecer a acção dos agricultores neolíticos, ou o estudo dos esquimós Nunamiut, o dos bandos de caçadores-recolectores do Paleolítico Superior (BINFORD, 1988). Mas não são menos importantes nem a Arqueologia experimental nem a caracterização dos materiais arqueológicos por métodos científicos, domínio de análise que se tem desenvolvido extraordinariamente desde a década de 1960.

As acções técnicas do passado, que consistiram em fabricar alguma coisa ou em explorar a natureza, não são directamente observáveis; mas, através dos vestígios materiais observáveis, que são o resultado das acções, podemos aceder às acções técnicas.

A maioria das acções sociais não deixa vestígios materiais observáveis. Que vestígios deixou a acção deste pai que, numa casa castreja, ralhou ao filho e lhe bateu? Mas há acções sociais que deixam vestígios. Não é o enterramento dos mortos uma acção social, e não deixa vestígios? Não puderam Shanks e Tilley (1982: 129-154) mostrar que os homens de Fussell's Lodge e Ramshõg não praticavam a inumação directa ou imediata? Enterravam ou expunham os cadáveres, recolhiam mais tarde alguns ossos de acordo com certas normas e empilhavam-nos na câmara funerária ainda segundo certas regras que os autores pu-

Conimbriga, 32-33 (1993-1994), 9-56 
deram determinar, representando-se assim a acção. Não é o ataque a uma aldeia uma acção social que pode ter deixado vestígios numa camada de incêndio?

As aç̧ões mânticas também podem deixar vestígios materiais, como estes ossos de galináceo nas fundações de uma casa romana, prova de uma acção contra o mau-olhado.

Perguntar pelo significado das coisas (destes ossos de galináceo, por exemplo) é inquirir das acções de que as coisas são vestígios. O vestígio é rasto, é aquilo que alguém deixou, aquilo a partir do qual reconhecemos uma acção.

O arqueólogo, partindo dos vestígios materiais, pode, pois, aceder às acções, embora não tenha delas uma representação tão clara como a das testemunhas presenciais.

Mas as aç̧ões, como vimos, implicam ideações, desejos ou aversões, volições e execuções. A ideação, por seu lado, implica, como também vimos, uma definição de fins e uma definição de meios necessários à concretização desses fins. $\mathrm{O}$ arqueólogo constantemente pergunta pelos fins. Com que fim se enterravam, nas fundações das casas, os ossos de galináceos? Com que fim se cavavam, nos oppida da Idade do Ferro da Inglaterra, estas fossas? Para servirem de lixeiras? Para servirem de silos? Com que fim construíam os índios as fossas fumacentas (BINFORD, 1972: 33-58)? Para afugentar os mosquitos? Para curtirem peles? É pacífico, pois, que o arqueólogo parte das coisas feitas para a acção, do opus operatum para o opus operandi, e que procura descortinar os fins.

Os meios estão aí, observáveis, materializados na execução. Se o fim dos índios era curtir peles, que meio escolheram para fazê-lo? As fossas fumacentas. Se o fim dos construtores deste dolmen era garantir a estabilidade dos esteios, que meio escolheram para alcançar esse fim? A construção de contrafortes. Se o fim do construtor desta casa castreja era demonstrar a sua preeminência social, que meio escolheu? Decorou a verga e as ombreiras da porta.

Os desejos ou as aversões, porém, não são alcançáveis. O agente desta acção executou-a desejando-a ou avertindo-a? Como sabê-lo?

A volição, reduzida à deliberação de executar o ideado, é também um facto mental não reconstituível: reconstituímos o que foi ideado e observamos o que foi executado mas não podemos aceder ao acto de querer.

A execução, momento final da acção, essa pode reconstituir-se, como acabámos de ver: podemos imaginar como é que o artífice meta-

Conimbriga, 32-33 (1993-1994), 9-56 
lúrgico fundiu o machado, como é que os construtores deste dolmen o ergueram, etc.

A acção tem uma duração que, tal como a da coisa, pode ser objectiva ou subjectiva. Esta acção pode ser vivida por mim como breve, porque me deu prazer; e esta outra, que durou exactamente o mesmo tempo objectivo, como longa, porque me foi penosa. A duração subjectiva das acções dos homens do passado é, evidentemente, irrecuperável. A duração objectiva é também difícil de determinar: quanto tempo durou a construção deste dolmen ou destas muralhas? Através da Arqueologia experimental ou da Etnoarqueologia pode, nalguns casos (limitados), fazer-se uma ideia de quanto tempo terão durado certas acções: cobrir esta casa de colmo, abater uma árvore com um machado de pedra polida.

A acção, para além de uma duração, tem um desenvolvimento temporal. Isto significa que ela aparece primeiro ao agente como um futuro, isto é, como qualquer coisa a realizar; depois, como um presente, qualquer coisa que se realiza; finalmente, como um passado, coisa realizada. Existe também uma distância temporal entre a concepção e a realização, na medida em que eu posso realizar uma acção na sequência imediata da sua ideação, ou muito depois de a ter pensado.

A acção feita, o opus operatum, vai-se distanciando do meu presente: foi feita há pouco, ontem, há duas luas, no tempo em que meu pai era ainda vivo, até se afastar num passado indeterminado. Quer dizer que a acção feita vai sendo progressivamente recolocada ou recentrada; a acção vai deslizando no tempo, duma forma que Merleau-Ponty (1945: 477) examinou exemplarmente, aliás de acordo com Husserl (1964; vid. também GELL, 1992: 221-241).

Este desenvolvimento temporal da acção não pode ser imaginado, muito menos vivido pelo arqueólogo. A comunidade que concebeu este dolmen ideou-o para ser realizado de imediato? ou para ser realizado a médio prazo? e quando é que a acção caiu nesse passado indeterminado a que nos referimos? ao fim de vinte luas? de cem? A perguntas deste género não podemos responder.

Concluiremos que, podendo imaginar as acções do passado, não podemos representar-nos a sua duração subjectiva nem o seu desenvolvimento temporal e só em poucos casos podemos representar-nos, aliás sem muita segurança, a sua duração objectiva. Tudo o que nós, arqueó- 
logos, podemos fazer com alguma segurança é situar a acção num tempo cronométrico, por exemplo, em 3100 a. C., tempo que não é, obviamente, o tempo vivido do agente.

A acção social, sendo uma acção entre sujeitos, implica um que a executa (o agente) e outro que a sofre (o paciente). Podemos falar de acção social colectiva quando não existe um, mas vários agentes, ou quando não há só um, mas vários pacientes. $\mathrm{O}$ ataque de um grupo armado a uma aldeia é uma aç̧ão social colectiva. Se, na realidade da prática, o agente pode ser, simultaneamente, paciente (como no caso de uma batalha ou refrega), não deixa de ser legítima e útil a distinção lógica entre agente e paciente.

$\mathrm{Se}$, para o(s) agente(s), existe um desenvolvimento temporal da acção, o(s) paciente(s) vivem a acção sob um determinado modo temporal. A acção sofrida pode ser um facto inesperado, um facto-surpresa. O assassinato de Viriato foi, talvez, para o próprio e para os Lusitanos que ele comandava, um facto inesperado, com que não contavam. Mas a aç̧ão sofrida pode ser vivida como facto esperado, aguardado. Este modo de ser temporal da acção sofrida é susceptível de três submodos possíveis: o facto pode vir em tempo certo, atrasado ou antecipado. A população de uma aldeia pode prever o ataque de que vai ser alvo; esse ataque pode sobrevir no dia previsto, ou depois do previsto, ou antes do previsto. O facto-surpresa é apenas um caso extremo do facto esperado.

O modo de ser temporal da acção sofrida parece incognoscível: sem fontes literárias, não podemos saber se este(s) paciente(s) espera$\mathrm{va}(\mathrm{m})$, ou não, a acção, e se esta sobreveio em tempo certo, atrasada ou antecipada. As obras de refortificação observáveis em muitos castros do Sul de Inglaterra podem ser interpretadas como reacção ao avanço das tropas romanas em 43-44 d.C. (CunLIFFE, 1991: 128); e o enorme monte de 22.000 pedras de funda encontrado junto de uma das entradas de Maiden Castle (CunlifFe, 1991: 118), como um municiamento preparado para a defesa do oppidum. Temos aqui, claramente, uma população que aguardava o ataque; mas casos como este são raramente observáveis. A população da área de Alcácer do Sal que, no séc. VII a.C., viu erguer-se a feitoria de Abul, esperava ou não a chegada dos Fenícios? É possível que sim, pois talvez os Fenícios tenham negociado a sua instalação. Mas como sabê-lo?

Assim, e em conclusão, diremos que o modo temporal de aparição da acção é incognoscível.

Conimbriga, 32-33 (1993-1994), 9-56 


\section{O tempo das normas}

A breve análise, a que procedemos, da dinâmica da acção tem de completar-se com um exame do modo normativo da acção. $\mathrm{O}$ cumprimentar o parente, o amigo, o conhecido é uma acção universal; mas um europeu ocidental não cumprimenta o outro da mesma maneira que um russo, nem este, da mesma maneira que um japonês. E não se cumprimenta o pai do mesmo modo que se saúda um amigo da mesma idade. Dar sepultura a um morto é igualmente uma acção universal; mas quantos modos não existem de enterrar! Uns incineram, outros inumam; estes que inumam divergem uns dos outros no ritual que adoptam.

A acção obedece a normas que são culturalmente específicas e é a divergência ou a multiplicidade das normas que explica a variabilidade dos modos de acção: a norma produz o modo.

Se distinguimos acções técnicas, de acções sociais e de acções mânticas, devemos correlativamente distinguir normas técnicas, que orientam as primeiras, de normas sociais, que determinam o modo das segundas, e de normas rituais, que condicionam as acções mânticas.

O sujeito que age, concebendo a acção, ouvindo seus desejos, determinando-se a agir e, por fim, agindo, não o faz sem atender a normas: há acções que devem ser praticadas e outras que não devem sê-lo, e as primeiras devem sê-lo de determinada maneira. O sujeito é livre para conceber qualquer acção mas não é inteiramente livre para agir porque há determinadas normas técnicas, sociais ou mânticas que estruturam ou conformam a acção.

Devemos acrescentar que a acção não é condicionada só pelas normas, mas também pelas condições objectivas da existência: eu posso conceber matar alguém e não executar esse acto porque há uma norma social que me proíbe de matar o outro; posso conceber comprar um carro de luxo e não o comprar, não porque exista norma social que mo proíba, mas porque não tenho dinheiro. Poderíamos pensar que as condições objectivas da existência não determinam o modo da acção, mas apenas a acção possível e a acção impossível, ou a acção legítima e a acção ilegítima. Todavia, se pensarmos na linguagem, hoje obsoleta, dos cartões de visita, seremos forçados a concluir que as condições objectivas da existência podem determinar o modo. Os nossos avós, quando visitavam alguém, entregavam um cartão de visita à criada que vinha abrir-lhes a porta. De que modo o faziam? Se o visitado estava em casa, entregavam o cartão, sem mais, para que o visitado soubesse 
quem era a visita. Se o visitado estava ausente, entregavam o cartão dobrado de acordo com um código social: no canto inferior esquerdo se se consideravam socialmente inferiores; no canto superior esquerdo, se se tinham por socialmente superiores; a meio, se se consideravam iguais. As condições objectivas da existência (neste caso, a posição social relativa) comandavam o modo como se dobrava o cartão.

A norma não existe independente de um contexto: matar alguém pode ser socialmente ilegítimo, mas acção socialmente aceitável e não punível se em legítima defesa ou, por exemplo, para salvar a honra (como, em certas sociedades, no caso do marido que mata o amante da mulher).

Assim, a acção é condicionada pelas normas, pelas condições objectivas da existência e pelo contexto.

As normas são, para alguns sociólogos e antropólogos, regras objectivas, formais e explícitas, de que o sujeito tem consciência quando age: não são meras leges insitae, isto é, normas tão interiorizadas que se tornam inconscientes.

A posição epistemologica que faz das normas um código objectivo de que o sujeito tem clara consciência e que pondera quando age vai a par com a concepção da acção como uma estratégia, um plano reflectido. Ora, como observa Bourdieu (1990, particularmente book I, chaps. 3 e 5), a maioria das nossas acções não é planeada, reflectida, mas espontânea. Não nos perguntamos, a cada instante: que vou fazer? como vou fazer? desejo ou não que se realize a acção pensada? está esta acção de acordo com as normas, as condições objectivas da minha existência, o contexto?

Numa leitura superficial, poderíamos pensar que Bourdieu nega a acção como cálculo consciente; na realidade, faz dessa acção calculada apenas um modus operandi, uma maneira de agir; mas há outro modus operandi, que é o modo como se realiza a maior parte das nossas acções, modo esse a que Bourdieu chama habitus. O habitus não pressupõe "uma intenção consciente ou um domínio expresso das operações necessárias à concretização dos fins" (1990: 53); é um modo "regulado e regular que não é de maneira nenhuma o resultado de uma obediência a regras" (1990: 53); é uma "espontaneidade sem consciência ou volição" (1990: 56). A Bourdieu não interessa a análise da acção consciente e reflectida; mas não a nega; simplesmente o que pretende é analisar o outro modus operandi, aquilo "que o habitus realiza de modo totalmente diferente" (1990: 53), modo esse espontâneo, que não ponde-

Conimbriga, 32-33 (1993-1994), 9-56 
ra as regras, modo em que não intervem a razão discursiva, modo em que a norma agora é lex insita, imanente e inconsciente. No habitus, a acção aparece-nos de imediato como correcta ou incorrecta, adequada ou inadequada sem termos necessidade de suspender ou adiar a acção pensada ou ideada para verificar se está ou não de acordo com as normas antes de nos decidirmos a executá-la. A natureza da acção reside na ausência de razão ponderada; a prática, por definição, segundo Bourdieu, exclui o pensamento explícito.

Se, descendo eu uma rua, vejo que vem por ela subindo um conhecido, não me pergunto que devo fazer quando nos cruzarmos: o "bom dia" vem-me espontaneamente.

O habitus, porém, não exclui a norma: só que esta não é aplicada de forma consciente, discursiva, reflectida; é aplicada sem ser pensada; é lex insita, lei imanente, inconsciente. Para a designar, Bourdieu prefere, ao nome de norma, o de esquema generativo da acção.

A distinção de dois modus operandi, um caracterizado pela aplicação consciente de normas, outro pela aplicação irreflectida, é certamente uma distinção pertinente e útil; mas não podemos deduzir daqui que os esquemas generativos da acção, isto é, as normas insconscientemente aplicadas, não possam ser trazidas ao plano da consciência, objectificadas pelo agente.

Muitos comportamentos são miméticos: eu comporto-me desta maneira porque vejo os outros agirem desse modo. Como disse Aristóteles \{Poética, 1448 b), o homem é o mais imitador dos animais e aprende suas primeiras lições pelo mimetismo. O mimetismo exclui a consciência das normas porque o que é objecto de percepção e de reprodução não é a norma, mas o comportamento concreto normalizado. “...Os esquemas podem passar directamente de prática a prática sem passarem pelo discurso e pela consciência" (BOURDIEU, 1990: 74): a prática pode transmitir-se no estado prático sem passar pelo plano do discurso.

A aprendizagem da língua materna é um exemplo de mimetismo: essa língua, ao contrário das línguas estrangeiras, aprende-se sem que as regras sejam discursivamente assimiladas. Mas a aprendizagem mimètica é geralmente acompanhada por aquilo que podemos chamar indoutrinação, isto é, pelo ensino discursivo das normas. Como é que a criança aprende a servir-se dos talheres senão, simultaneamente, pelo mimetismo e por assimilação de regras que os pais formulam discursivamente? 
Os esquemas generativos da acção, ou muitos destes esquemas, sendo leges insitae, foram, na origem, também normas conscientes que depois cairam no inconsciente e que podem a qualquer momento ser de novo trazidas à consciência quando o agente se distancia da própria prática convertendo esta em objecto do conhecimento e de interrogação.

A pergunta das crianças é um mecanismo motor desse trânsito das leges insitae a normas conscientes. Quando a criança pergunta "porque fazes isto?" ou "porque fazes isto desta maneira?", obriga-nos a chamar à consciência as regras generativas da acção. $\mathrm{O}$ mesmo sucede quando o antropólogo formula o mesmo tipo de perguntas a um primitivo. Bourdieu parece esquecer que a norma está constantemente a advir à consciência para regressar ao inconsciente, ao automatismo e daí, de novo, emergir à superfície da consciência.

Admitindo que a norma, podendo funcionar como lex insita, pode todavia também a qualquer momento ser interrogada, objectificada, abstraída do comportamento (no sentido etimológico, abstrahere, arrancar, tirar de), como é que a norma nos aparece quando se transforma em objecto do conhecimento, quando, da prática, passamos à reflexão sobre a prática? Aparece-nos como permanente e necessária, como qualquer coisa que foi, é e será, como aquilo que já regulou o comportamento dos meus antepassados e continuará a regular o dos vindouros e como regra a que devo obedecer, sob pena de sanções, sejam elas a reprovação dos outros ou a ineficácia da minha acção. A permanência e a necessidade estão tão interligadas que não podemos dizer se é a necessidade que fundamenta a permanência, ou esta que funda a necessidade.

Devemos precisar: é assim que a norma aparece a um sujeito destituído da consciência da historicidade. Para esse, a norma já aí estava quando nasceu. A origem dela, não a sabe. O primitivo remete a origem da norma para um tempo mítico, o tempo da geração do mundo. $\mathrm{O}$ mito é um mecanismo para explicar a origem das normas, é o ópio do selvagem que não o deixa representar-se as normas como produto das condições objectivas da existência e, por conseguinte, como mutáveis. $\mathrm{O}$ mito pretende abolir o tempo, e com ele, o devir, pretende escorar o presente para impedir que ele se torne passado (LÉVI-STRAUSS, 1986: 542). $\mathrm{Ou}$, como disse Eliade, o homem primitivo suprime o tempo "pela imitação dos arquétipos e pela repetição dos gestos paradigmáticos". Por esta repetição "há uma abolição implícita do tempo profano, da dura- 
ção, da "história"; aquele que reproduz o gesto exemplar é transportado assim para a época mítica em que esse gesto exemplar foi revelado" (ELIADE, 1993: 49-50).

Se a minha vida vem do futuro para o presente e desliza deste para o passado, nessa síntese de transição de que fala Merleau-Ponty (1945: 480; vid. também HUSSERL, 1964: 43), se a vida, no seu fluir, é o futuro que se torna um agora e um agora que logo se transforma num outrora, a norma vem do passado para o presente, para se continuar (isto é, para continuar a ser aplicada) no futuro. A norma é tradicional, no sentido original de traditio, que é entrega, transmissão de alguma coisa que alguém traz e passa a outro, que a leva mais longe (sobre o sentido de traditio vid. CRUZ CRUZ, 1993, passim). A norma é coisa do passado que existe no presente mas não apenas sob a forma de recordação ou sob a forma de ter sido, porque permanece activa e constrangente.

A norma, observada pelo cientista (no nosso caso, pelo arqueólogo), não é permanente nem necessária, mas pelo contrário, transitória $\mathrm{e}$ contingente. A perspectiva que o arqueólogo tem da norma não é a perspectiva que dela tem o agente, mesmo quando este objectiva a norma. O arqueólogo temporaliza a norma, situa-a num tempo cronométrico, procura explicá-la pelas condições objectivas da existência, tornando-a contingente, histórica.

Regras do jogo jogado, para o agente, as normas são regras do jogo observado de fora, para o investigador, situado numa posição que lhe permite entender como é que as normas são determinadas pelas condições objectivas da existência que, todavia, também estruturam, num movimento de retroacção em que a causa se torna efeito e o efeito, causa, pelo menos reforçando, se não originando, essas condições da existência.

E tão evidente que a Arqueologia estuda normas, que não carecemos de dar muitos exemplos. Normas técnicas, como a maneira de os Romanos armarem um telhado. Normas estéticas, como a do "sorriso arcaico" dos Kouroi gregos. Normas sociais, como as que se observam nos enterramentos. Normas religiosas, como os rituais de sacrifício aos deuses.

O tempo objectivo das normas, isto é, o lapso de tempo durante o qual certas normas serviram de normas, é determinável pelo arqueólogo. 


\section{O tempo dos aparelhos políticos}

Ñas sociedades primitivas, as relações de parentesco são suficientes para garantirem a unidade e estabilidade do grupo; mas à medida que este cresce e se acentuam nele as desigualdades económicas, criam-se antagonismos e contradições que exigem funções políticas institucionalizadas: surge um chefe e uma máquina do poder, que aqui designamos por aparelho político. $\mathrm{O}$ aparelho serve para manter a unidade $\mathrm{e}$ o equilíbrio interno da sociedade, para garantir a sua reprodutividade e para organizar as relações exteriores do grupo com outros grupos.

Os aparelhos políticos constituem, de todos os planos que o arqueólogo pretende investigar, o de acesso mais difícil: é mais fácil descobrir as ideias e as práticas religiosas de que os aparelhos políticos.

Ao contrário das coisas e das acções que, sendo pensadas antes de serem feitas ou praticadas, vêm do futuro ao presente, para deslizarem no passado que a memória recorda, os aparelhos, como as normas, vêm do passado para o presente, para se continuarem no futuro.

Os aparelhos têm uma duração que, em certa medida, depende da ideia que a sociedade se faz da origem das instituições. Esta pode ser situada num tempo mítico e as instituições podem ser atribuídas a um ser, sobrenatural ou carismático, que criou os aparelhos. Não atribuíam os Tartéssios a origem das suas instituições políticas a um rei mítico, Habis? Os aparelhos cuja origem é situada num tempo mítico exigem a fidelidade, a conformação; excluem a revolta ou o simples pensamento de que o futuro pode ser diferente do passado. Os aparelhos são assim reificados e, " através da reificação, o mundo das instituições parece fundir-se com o mundo da natureza. Torna-se necessidade e destino..." (BERGER e LuCKMANN, 1976: 125). Isto não quer dizer que sejam absolutamente imutáveis: as práticas flexibilizam os aparelhos e acabam por modificá-los na longa duração, insensivelmente.

O ocaso do tempo mítico e a aurora do tempo em que os homens se sentem responsáveis pelos aparelhos que os governam tornam possível o devir das instituições.

O devir dos aparelhos implica a consciência da sua mutabilidade: os aparelhos não evoluem por eles próprios, mas pela acção humana, e essa acção só pode ter lugar quando os aparelhos aparecem como aquilo que pode ou deve ser mudado. A consciência da possibilidade ou da imperatividade da mudança dos aparelhos fundamenta o projecto de mudá-los. Ora, o que pode ou deve ser mudado tem necessariamente de 
sê-lo no tempo. O tempo é, pois, o lugar da mudança que se projecta. Mas o que se pretende mudar pode apresentar-se como aquilo que pode ou deve ser mudado no presente, não podendo ou não devendo tê-lo sido anteriormente, ou como o que podia ou devia ter sido mudado há muito tempo. Quer dizer que a mudança pode ser o que acontece em tempo certo, ou o que já devia ter acontecido há muito tempo. Não há, porém, perspectiva social unitária da mudança: o que a uns aparece como devendo ser mudado, aparece a outros como devendo ser mantido; e aqueles a quem a mudança aparece como necessária ou inevitável podem ainda concebê-la como devendo ter lugar já, ou como por enquanto inoportuna e por isso ainda adiável.

A mudança dos aparelhos processa-se geralmente de forma lenta, num tempo de longa duração: os aparelhos vão-se actualizando lentamente, respondendo aos estímulos representados pelas tensões sociais que surgem no interior do grupo, tensões que podem agora acentuar-se, e logo, distender-se. Mas os aparelhos não são um mero produto das tensões sociais, na medida em que retroagem sobre elas, agravando-as ou relaxando-as. A mudança, porém, pode dar-se subitamente, num tempo que Gurvitch chama "tempo de ilusão", o qual, "sob a aparência da longa duração e do retardador, oculta virtualidades de crises bruscas e inesperadas" (1986: 385).

\section{O tempo das paisagens}

O homem, se vive necessariamente com outros homens, vive com eles, não menos necessariamente, num espaço, num meio: o homem é ser no mundo (HEIDEGGER, Être et temps, $\S \S 12$ e 13). Ora, este mundo suscitava certamente, nos primitivos, dois projectos: o de apropriação e o de exploração. O espaço era percebido como algo que era do grupo, que lhe pertencia, e não a outros grupos, e como algo que potenciava a subsistência.

Os caçadores-recolectores tinham já o sentido da territorialidade, isto é, o sentido de que dispunham de um espaço próprio e privativo, ao qual os outros bandos não podiam nem deviam, em princípio, ter acesso. Isto não excluía a ideia de que aos outros podia eventualmente ser facultado o acesso ao território do bando, em ocasiões de crise para eles. A condição de possibilidade de acesso seria a existência de relações de solidariedade entre bandos, relações que seriam criadas por laços matrimoniais. 
O espaço natural dos bandos de caçadores-recolectores era percebido como metamorfoseável, como podendo (ou devendo) transformar-se no tempo: apresentava vários aspectos consoante as estações, cobrindo-se eventualmente de geadas ou de neves no inverno, reverdecendo na primavera. O espaço aparecia assim como sujeito a transformações cíclicas.

O espaço aparecia aos caçadores-recolectores como algo dado, mas não como algo constmído. A percepção do espaço como algo de construível, de transformável pelo trabalho, só emergiu, provavelmente, com os primeiros agricultores. Tem-se definido o Neolítico em termos técnicos (como o tempo da pedra polida e da cerâmica) ou económicos (como o tempo em que começou a praticar-se a agricultura e a domesticação dos animais), esquecendo a dimensão ideológica da revolução neolítica, sobre a qual só muito recentemente começou a reflectir-se, no âmbito da Arqueologia contextuai. A nova visão do espaço como transformável por meios humanos, como aquilo que se pode construir, é talvez um dos fenómenos a integrar nessa revolução ideológica neolítica.

A construção do espaço, para os agricultores do Neolítico, era algo que se dava no tempo, diríamos melhor, algo que se tinha dado no tempo dos antepassados, de quem haviam recebido, como herança, o espaço construído, que todavia modificavam ainda, construindo, por exemplo, outro dòlmen que ficava aí, na paisagem, para os vindouros.

O sentimento da transformabilidade do espaço no tempo seria, todavia, no Neolítico, ainda limitado, na medida em que eram pequenas as transformações introduzidas em cada geração. Se os efeitos da erosão, por virtude da desflorestação, eram demasiadamente lentos para poderem ser percebidos, o esgotamento dos solos era talvez suficientemente rápido para permitir a sua percepção e obrigava a deslocar, a intervalos, a posição das aldeias; mas o espaço abandonado ficava aí, capaz de uma regeneração que iria permitir o regresso, reforçando a visão do tempo como cíclico.

Não é o arqueólogo que, pela sua visão à distância, no tempo, introduz uma noção de transformabilidade do espaço de que os homens primitivos careceriam em absoluto. Mas é óbvio que, numa relação existencial do homem com o espaço, este aparece como transformável muito mais lentamente do que na nossa representação de arqueólogos, nessa visão que, uno intuitu et tota simul, abarca vários séculos ou mesmo milénios. Temos necessidade de pensar que, para o primitivo, o espaço evoluía no tempo muito lentamente, quase imperceptivelmente. 


\section{Duração, sucessão e processo}

As coisas e as acções, como vimos, têm ou podem ter, para o utilizador e o agente, uma duração subjectiva. Porque o arqueólogo estuda o passado, digamos que as coisas e as acções tiveram ou podem ter tido uma duração subjectiva. Não podemos, nunca, reconstituir essa duração. Não é porque a vivência seja intransmissível: pode sê-lo pelo discurso ou por sinais. $\mathrm{O}$ outro pode dizer-me que a tarefa lhe está a parecer demasiadamente longa. Os movimentos de impaciência que faz o meu vizinho, coespectador no cinema, são sinais que me revelam que o filme lhe está a parecer lento. Mas a duração subjectiva só pode ser comunicada de sujeito a sujeito, de um ao outro, numa relação intersubjectiva que faz, de um, comunicante, e de outro, ouvinte ou interpretante, relação que, evidentemente, não podemos ter com os homens do passado.

As coisas e as acções tiveram, porém, também uma duração objectiva: o fabrico desta lança demorou tantas horas; a construção deste dólmen, tantos dias; esta casa durou tantos anos.

São poucos os casos em que a duração objectiva é determinável. Renfrew (1973: 547) calculou que a construção do henge de Avebury exigiu 1.500.000 horas de trabalho e a de Stonehenge, 10.000.000; mas como não sabemos quantos homens estiveram envolvidos no trabalho, não podemos determinar quantos meses ou anos demorou a construção destes monumentos. Soudskÿ (citado por RENFREW, 1973: 546) mostrou que as aldeias neolíticas dos terrenos loéssicos da Checoslováquia duravam cerca de 15 anos, ao fim dos quais a população abandonava o local porque a produtividade das terras estava esgotada, voltando ao mesmo ponto 60 anos depois (mas, para uma crítica desta tese da itinerância cíclica vid. BARKER, 1985: 141 e BOGUCKY, 1988: 81). Todorova (cit. por BAILEY, 1990: 30) mostrou que as casas do horizonte IV de Ovcarovo (Bulgária) duraram 82 anos.

Poderíamos citar muitos outros exemplos desta preocupação actual dos arqueólogos em calcular a duração objectiva de coisas e acções (pelo menos, acções técnicas), muitas vezes recorrendo à Etno-Arqueologia ou à Arqueologia experimental. Mas o que agora nos interessa é examinar como é que essa duração objectiva pode ser apreendida pelos utilizadores e agentes (neste caso, os homens pré-históricos) e por nós, arqueólogos.

Imaginemos o camponês neolítico das terras actualmente checas abandonando a aldeia em cuja fundação tinha participado sendo crian- 
ça, jovem ou mesmo já adulto. Da fundação da aldeia, esse camponês tivera uma percepção, essa percepção pura bergsoniana que "por definição apreende objectos presentes" (BERGSON, 1953: 78); agora, no momento do abandono, recordava esses actos fundacionais, situando-os no seu (dele) passado. No momento do abandono, a fundação da aldeia era evocada, chamada pela memória, que é essa faculdade de alguém se representar um objecto ausente (BERGSON, 1953: 79), de o reter no presente sendo todavia já passado. A acção recordada tem necessariamente uma data (BERGSON, 1953: 84, 88), isto é, uma posição na história pessoal de quem se recorda. Eu recordo-me de isto ter sucedido antes ou depois de um outro sucesso. Chamemos, a este conhecimento, empírico (de empeiría, experiência): conhecimento por vivência.

Imaginemos agora um homem do Neolítico enterrando um familiar num dólmen ao lado de outro dólmen já abandonado. Da fundação e do abandono do primeiro dólmen, este homem não tivera vivência. Não podia situar essa fundação e esse abandono na sua história pessoal: o dólmen estava feito e abandonado, estava já aí quando aquele homem tinha tomado consciência de si, sempre o tinha visto naquele lugar desde que se recordava de si. Mas esse homem podia ter conhecimento da duração objectiva do dólmen: podia saber, por informação de algum velho do grupo, que havia sido construído no tempo do seu quarto avô e abandonado no tempo do seu pai. Temos aqui um outro tipo de conhecimento, a que chamamos narrativo: conhecimento da duração por informação de uma testemunha presencial ou por informação de alguém que também não foi testemunha presencial mas que recebeu a informação de uma testemunha presencial, numa cadeia que pode ter muitos elos. Os factos, agora, não são vividos, mas comunicados, contados, noticiados e a notícia transmite a data ou a duração. Na África há comunidades cujos anciãos memorizam crónicas que vão até 1300 da nossa era (TOULMIN e GOODFIELD, 1967: 27).

É de um terceiro tipo o conhecimento que o arqueólogo tem da duração objectiva. Chamemos-lhe conhecimento epistémico (de episte$m e$, ciência). $\mathrm{O}$ arqueólogo não recebe a informação através da crónica oral ou escrita. Tem de descobrir a duração através de sinais que interpreta (e, neste sentido, poderíamos também chamar a este conhecimento, hermenêutico). $O$ arqueólogo determina a duração desta villa romana pela data que atribui aos materiais encontrados nas valas de fundação dos muros e pela cronologia que define para aqueles outros materiais que recolhe sob as telhas da cobertura abatida. 
No primeiro caso (o do camponês neolítico), temos datas conhecidas por experiência directa e integradas numa historia pessoal; no segundo (o do homem do horizonte megalítico), uma data transmitida por um narrador a um ouvinte e integrada numa história social, numa história do grupo; no terceiro, uma data reconstituída a partir de sinais, uma data que se inscreve numa escala cronométrica, num tempo vazio de factos, e não numa história: a história vem depois, quando, estabelecido um certo número de datas para um certo número de factos, se toma possível encadeá-los numa sucessão. A percepção do arqueólogo é uma percepção metódica, analítica, diferente da vivência, da retenção (na memória) e do conhecimento por ouvir dizer, nenhum das quais exige análise, método ou razão.

Qualquer um dos conhecimentos que acabámos de distinguir exige uma escala cronométrica. A do camponês neolítico ou a do utilizador do dolmen seria uma escala em luas, em estações, em gerações? A nossa é em anos, a partir do nascimento de Cristo, para um lado e o outro. O arqueólogo, usando escala diferente da dos homens pré-históri$\cos$, não atribui todavia uma duração objectiva a coisas e acções que não tenham tido duração objectiva para os utilizadores e os agentes: o homem pré-histórico sabia que este machado e este dólmen, feitos agora, iriam atingir algum dia o limiar da utensilidade. Isto não quer dizer que nós, arqueólogos, vejamos as coisas como as viram os homens do passado: estes viam as coisas de que se serviam como coisas prestáveis, coisas com uma potencialidade activa; nós vemos as coisas como potencialidades concluídas, como coisas de que não nos podemos servir, como utensílios sem utilidade. O mundo que desvendamos, e que foi um mundo em que os sujeitos estavam activos, servindo-se das coisas, é agora um mundo posto fora de acção. Mas os homens que deixavam de enterrar num dólmen por este estar cheio (ou por qualquer outra razão) e construíam outro dólmen, os homens que destruíam uma casa por estar velha e construíam outra casa, nova, não viam também o primeiro dólmen e a primeira casa como potencialidades concluídas?

No caso das normas e dos aparelhos, nós representamo-los de um modo sob o qual nunca os homens do passado os representaram. Para estes, as normas foram, como vimos, permanentes, intemporais, necessárias; nós percebemo-las como transitórias, contingentes, explicáveis por e relacionáveis com as condições objectivas da existência. A norma, para o arqueólogo, é a regra de acção que já não estrutura a acção; o aparelho é esse nível organizado coercivo (GURVITCH, 1986: 391) que já não exerce coerção. 
Voltando ainda às coisas, se não é fácil determinar a duração delas (desta precisa ânfora, desta concreta peça de terra sigillata), é pelo menos possível determinar a duração dos tipos em que elas se integram: o tempo durante o qual foi fabricado este tipo de ânfora ou esta forma de terra sigillata.

A determinação da duração objectiva das coisas ou dos tipos, das acções, das normas, dos aparelhos, das paisagens, não é o único objecti vo do arqueólogo: este procura também estabelecer sucessões.

As coisas são substituídas, ou fabricam-se coisas novas enquanto outras se abandonam por se terem tornado inúteis; as acções vêm umas a seguir às outras; as normas alteram-se, revêem-se, substituem-se; os aparelhos transformam-se; as paisagens evoluem, passam de um estado a outro estado. Em qualquer plano em que nos situemos (no da cultura material, no dos factos económicos, sociais, políticos ou ideológicos), há sempre uma sucessão. Esta é uma “ordem cujo princípio ordenador é o da relação antes-depois" (SARTRE, 1993: 150).

O estabelecimento dessa relação não implica necessariamente o posicionamento prévio exacto dos factos numa escala cronológica: não é preciso sabermos que este facto se deu nesta data e este outro nesta outra para situarmos o primeiro anteriormente ao segundo. Quando escavamos, podemos verificar que uma estrutura se encontra por debaixo de uma outra: essa posição estratigráfica indica a anterioridade da primeira. Ou que um muro se adossa e não se trava num outro, o que nos permite concluir da posterioridade do primeiro, que foi acrescentado a um anteriormente existente. $\mathrm{O}$ estabelecimento de sucessões sem datas exactas é corrente na prática arqueológica, embora sempre procuremos, depois, estabelecer essas datas, convertendo em absoluta a cronologia relativa.

As sucessões que o arqueólogo traça ou constroi não são ficções: correspondem a sucessões reais. A evolução das casas do Neolítico danubiano de planta rectangular para planta trapezoidal, a evolução dos tumuli alentejanos de circulares (na Idade do Bronze) para quadrangulares (na Ia . Idade do Ferro), ou ainda a progressiva substituição da norma de incineração pela da inumação, no Império romano, a partir do séc. II d. C., foi uma evolução real.

Dada a temporalidade dos homens e dos grupos, tudo quanto acontece a uns e outros acontece necessariamente em sucessão: os factos acontecem uns depois dos outros. A vida é essa "narratividade incoativa", essa "história potencial", essa "história (ainda) não contada" 
de que fala Ricoeur (1983: 113-114). A historia acontece antes que alguém a conte, ou mesmo que ninguém a conte. A acção está aí, no passado, à espera que alguém a conte ("l'action est en quête de récit", RICOEUR, 1983: 113).

Narrando, o arqueólogo, tal como o historiador, procura compreender e explicar o passado. Afastar-nos-íamos muito do nosso intento se introduzíssemos aqui uma teoria da compreensão e da explicação. Seria talvez útil tal reflexão, não obstante ter Ricoeur elaborado exemplarmente essa teoria (por exemplo, em RICOEUR, 1983 ou 1990): se o autor tem da historiografia e da filosofia critica da história um profundo conhecimento, ignora o trabalho específico do arqueólogo, a partir de cuja perspectiva poderíamos talvez refazer a teoria da compreensão e da explicação. Mas julgamos mais oportuno desviar agora a nossa atenção para outro problema: muitos trabalhos arqueológicos não estabelecem sucessões, mas estudam configurações sem movimento.

A Arqueologia, ao contrário da História (pelo menos, da "histoire événementielle"), é uma história sem personagens. Não quer isto dizer que o arqueólogo não encontre o indivíduo. Não encontramos nós o túmulo da princesa de Vix ou do príncipe de Hochdorf? Mas esse indivíduo que encontramos é alguém sem nome e sem rosto, alguém de quem não sabemos nada, senão que foi enterrado ali, em certa data, alguém de quem não podemos escrever uma biografia, por mais sumária que seja. E se, para cada artefacto, temos de postular a existência de alguém que o fez e de alguém que o usou, nada sabemos desse fabricante e desse utilizador: o quem é um referente sem conteúdo.

O sujeito da Arqueologia é o grupo social, esse grupo que construiu as muralhas de Vila Nova de S. Pedro ou a feitoria de Abul e ali viveu. O quem do arqueólogo é o grupo, o on francês, o Mann alemão. A Arqueologia nega o indivíduo, dissolvendo-o no anonimato do grupo, não por opção, mas por necessidade. Pelo contrário, esse interesse da historiografia contemporânea derivada dos Annales pelo estudo das conjunturas e das estruturas, das tendências e das crises, em prejuízo da "histoire événementielle", esse eclipse da narração ("éclipse du récit"), como lhe chamou Ricoeur (1983), é uma opção. Não é por necessidade, mas por escolha, que alguns historiadores contemporâneos preferem a história anónima, profunda e silenciosa de que fala Braudel (1983).

Se o grupo é o sujeito da Arqueologia, o que nós procuramos são os traços configuradores ou caracterizadores desse grupo, aquilo que 
define a sua ecceidade, a sua personalidade própria: a sua cultura material, a sua forma de vida economica, a sua organização social, as suas instituições políticas, a sua ideologia. O esforço de Childe para catalogar o "conteúdo de urna cultura" (CHILDE, 1969: 145-148) proporciona ainda um útil inventário do que são os traços configuradores, não obstante lhe faltar a visão sistémica que a Nova Arqueologia posteriormente introduziu.

Os traços configuradores são predicados de um grupo mais ou menos vasto, consoante a perspectiva que adoptemos: podemos estudar um sítio, isto é, um grupo de co-residentes, um conjunto de sítios ou aquilo a que os arqueólogos chamam uma cultura.

Analisando os traços configuradores, temos de dar um princípio e um fim à história. Ora, "o tempo... apresenta-se-nos como uma linha de momentos, contínua e transcorrente, aberta e aperiódica, que vai passando numa determinada direcção desde um antes no sentido de um depois..." (EllaCURÍA, 1991: 331, sublinhado nosso). Se o tempo é aperiódico, a história dos grupos é epigenética (de epí, em posição superior ou ulterior e génesis, origem), isto é, no passado encontram-se as sementes do futuro: não há época, por revolucionária que seja, que não conserve traços do passado nem época, por muito tradicional que possa ser, que não contenha anúncios de futuro. Da continuidade da evolução deriva a extrema dificuldade de estabelecermos divisões em períodos e de marcarmos o princípio e o fim deles.

O facto, porém, é que os arqueólogos estabelecem períodos ou fases, tomando, como critério, mudanças consideradas significativas no plano da cultura material. Dada a sistematicidade da cultura (um sistema é um todo feito de partes interactuantes), a cultura material configuradora é solidária de uma forma de vida económica, de uma organização sociopolítica, de uma ideologia e a evolução de um destes planos determina ou arrasta a evolução dos outros. Não queremos tomar aqui parte no debate sobre se a evolução tecnoeconómica determina a sociopolítica e ideológica, ou o inverso: no fundo, as duas caminham a par, cada uma retroagindo sobre a outra, a causa tornada efeito, os fenómenos sociopolíticos e ideológicos condicionando a vida económica e a cultura material que, por seu turno, determinam aquelas. Não há influências unidireccionais, mas dialéctica dos subsistemas.

$\mathrm{Se}$ os acontecimentos ("événements") têm uma duração breve, os traços configuradores têm permanência. Por isso o arqueólogo, se não observar um lapso de tempo considerável, não vê mudança, não vê su- 
cessão, mas estabilidade, estagnação: vê um tempo sem devir. A percepção da permanência ou da sucessão dependem do princípio e do fím que o arqueólogo der ao lapso de tempo cronométrico observado. Se o fim for situado muito perto do princípio, numa escala cronométrica, a cultura do grupo parece imóvel e a sucessão desaparece; um lapso de tempo maior faz emergir a sucessão.

Passemos agora ao exame do conceito de processo.

O processo, como a sucessão, desenrola-se no tempo. Para analisarmos este conceito temos de examinar previamente os de causa e explicação, difíceis de definir devido à imprecisão da linguagem de arqueólogos e historiadores, que frequentemente apelidam de causas o que, afinal, são apenas razões.

Os nexos de anterioridade-posterioridade não podem confundir-se com nexos de causalidade, porque o que vem antes não é forçosamente causa do que vem depois, nem a anterioridade de um facto relativamente a outro constitui necessariamente uma explicação deste outro.

Quer a causa quer a explicação de um facto são o porquê ou a condição desse facto. A causa necessária de um facto $b$ reside no facto $a$ sem o qual o facto $b$ se não poderia ter produzido; a causa suficiente reside num nexo de necessidade entre os factos $a$ e $b$ : produzindo-se a, necessariamente se produz $b$.

A causalidade suficiente é um nexo que, pela sua necessidade, o homem não pode alterar: um incêndio foi a causa suficiente da destruição desta casa que acabámos de escavar; a tuberculose foi a causa suficiente da morte deste homem cujo esqueleto encontrámos neste túmulo. Os homens podem ter lutado contra o fogo ou contra a doença; mas, finalmente, foram vencidos por eles; e não foi preciso mais do que o fogo ou a doença para destruir a casa ou vitimar o homem.

A causalidade necessária mas não suficiente abre possibilidades: o facto $b$ não se poderia ter produzido sem o facto $a$; mas este poderia ter-se verificado sem que se produzisse o facto $b$. O contacto dos Cónios do Alentejo com os Tartéssios, no séc. VII a.C., tornou possível aos Cónios começarem a usar escrita; mas poderia ter havido esses contactos sem que os Cónios assimilassem a escrita.

Uma causa necessária, ou mesmo um cúmulo de causas necessárias, não permite entender totalmente um facto. A causalidade necessária simplesmente viabiliza ou reúne as condições de possibilidade; mas o possível não é o efectivo. Temos, assim, de perguntar-nos o que mais foi preciso para se passar do facto possível ao facto verificado. 
Ora, essa passagem operou-se por intervenção de alguém (indivíduo ou grupo) que agiu deste modo, com certas razões, podendo ter agido de maneira diferente. Certos autores consideram calculada essa acção. Assim, William Dray diz: explicar "é reconstruir o cálculo feito, pelo agente, dos meios que deve adoptar em vista do fim que escolheu tendo em atenção as circunstâncias em que se encontrava" (in Laws and explanation in History, citado por RICOEUR, 1983: 183-184). Este cálculo poderia identificar-se com a acção estratégica de Habermas, que é "aquela acção cuja racionalidade está ligada à avaliação das alternativas possíveis, tendo em vista o sucesso, sucesso que depende da compreensão das intenções de um parceiro racional" (FERRY, 1987: 338).

Convém todavia minimizar o cálculo, a estratégia, a racionalidade: a intervenção pode ser um fenómeno de ordem práxica, pode ser esse habitus de Bourdieu, que é "uma espontaneidade sem consciência ou vontade, tão oposta à necessidade mecânica das coisas sem história na teoria mecanicista como à liberdade reflexiva dos sujeitos "sem inércia" na teoria racionalista" (BOURDIEU, 1990: 56). Aliás, Dray reconhece que as "razões" podem ser paradoxalmente irracionais, isto é, não calculadas (ainda em RICOEUR, 1983: 185).

A intervenção tem, pois, razões mais ou menos reflectidas. Ora, as razões visam fins que não podem ser confundidos com causas (excepto no sentido em que a Escolástica falava de causae finales). E a descoberta dessas razões que constitui a explicação.

Analisando a evolução das casas do Neolítico danubiano, Hodder (1990: 119s) observa uma tendência para a passagem de uma planta rectangular a um formato trapezoidal: longas, as casas vão estreitando a largura da traseira e aumentando a da fachada; ao mesmo tempo, a trave do cume, donde descia a cobertura de duas águas, poderia ter-se tornado oblíqua, mais alta na fachada, mais baixa na traseira. Ao mesmo tempo que se processa esta evolução, com enfatização da fachada, observa-se uma concentração do povoamento: a população, inicialmente dispersa, reúne-se em aldeias. Há, portanto, uma modificação das relações sociais, com a criação de laços de vizinhança mais estreitos. Nas aldeias haveria competição pelo status social. Uma maneira de afirmá-lo seria através da arquitectura da casa: aumentando a largura e a altura da fachada, uma família construiria uma casa mais imponente.

Neste exemplo, são os fins ou as intenções que explicam a evolução das casas. Mas quando apresentamos a guerra entre populações pré-históricas como um resultado da pressão demográfica, que tornava a 
terra escassa e criava problemas de subsistência, estamos a definir uma causa suficiente.

Nesta perspectiva, podemos dizer que a Nova Arqueologia procura as causas suficientes e tende para uma lógica da necessidade, enquanto a Arqueologia contextuai procura as razões e se orienta para uma lógica da finalidade: a primeira procura as causas suficientes; a segunda, as intenções, que encontram, nas causas necessárias, apenas as condições de possibilidade da acção.

O caminho está agora desbravado para definirmos o que deve entender-se por processo: é o encadeamento de factos cuja sucessão se esclarece por causas suficientes, ou por causas necessárias acompanhadas de razões; é a demonstração de que o anterior gerou o posterior por efeito da necessidade ou da implicação, ou que o anterior continha as condições de possibilidade para uma intervenção que, por razões que têm de ser explicitadas, conduziram ao posterior. Se a sucessão estabelece um mero nexo de anterioridade-posterioridade, o processo é uma relação de um explanandum a um explanans. A sucessão implica o posicionamento numa escala temporal. Os factos assim posicionados são factos descontínuos; mas eles têm de ser relacionados em termos de causas e efeitos ou de intenções, numa síntese que esclarece porque é que uns derivam dos outros, ultrapassando a descontinuidade das sucessões para alcançar a continuidade dos processos.

Desenvolvendo-se no tempo, os processos têm um ritmo, que pode ser rápido ou lento: a evolução da cultura castreja do Noroeste de Portugal é mais rápida a partir dos fins do séc. II a. C. que entre os inícios do $10^{\circ}$ milénio e aquela data. Mas, porque a cultura é um sistema que integra vários subsistemas, podemos admitir que os subsistemas não evoluam todos ao mesmo ritmo: teremos, assim, um processo sincopado. Outras vezes, o processo é lento num lapso de tempo considerável, acelera-se num determinado momento (o tempo explosivo das crises e das revoluções) e volta a tornar-se lento: diremos, então, que o processo é descompassado, interrompido, a intervalos, por surpresas.

\section{O tempo do arqueólogo: uma intuição transcendental, ou uma construção capitalista?}

O tempo que nós, arqueólogos, postulamos é um tempo "homogéneo que nos representamos como lugar das sucessões. Com efeito,... 
pensamos espontaneamente que toda e qualquer mudança se passa no tempo (dans le temps). É nesse tempo que situamos os acontecimentos e que marcamos as suas posições respectivas. Ora, esse tempo indiferenciado... é figurado como uma linha contínua, medida pelo movimento periódico dos astros e o ritmo do relógio" (GRIMALDI, 1993: 11-12 , itálicos do autor).

Esta linha é dividida a espaços (temporais) mais ou menos curtos. Para situarmos os acontecimentos do passado mais longínquo, dividimos a escala em milénios; para situarmos os acontecimentos de um passado proto-histórico, em séculos, em meios-séculos, mesmo em quartos de século.

Contra esta concepção espacial do tempo, insurgem-se Shanks e Tilley (1993: 118 s.), como se fosse possível escrevermos a história de outra forma.

Os mesmos autores (SHANKS e TILLEY, 1993: 125) consideram este tempo espacial como um produto do capitalismo, esquecendo que ele foi o tempo de Gregos e Romanos, que até já tinham relógios. O que pode ligar-se ao capitalismo é, talvez, a noção de que o tempo é qualquer coisa que nós temos para gastar ou poupar, qualquer coisa que usamos, uns procurando rentabilizá-lo, esforçando-se por tirar dele o máximo proveito, porque "o tempo é dinheiro", outros desperdiçando-o, esbanjando-o, como se pode esbanjar a riqueza. O que se pode, talvez, atribuir ao capitalismo, é esse "culto da rapidez" de que fala Ferrarotti (1990: 78). Mas nem sequer este culto da celeridade, do bom aproveitamento do tempo, se pode atribuir ao capitalismo, porque radica na noção calvinista da perda de tempo como um pecado, como qualquer coisa repreensível, como tão bem esclareceu Max Weber (1983). O hiperactivismo calvinista não derivou do capitalismo, mas criou as condições morais do capitalismo. A noção de que o tempo tem de ser aproveitado é mesmo muito anterior ao capitalismo. Encontramo-la nos mercadores medievais (LE GoFf, 1979; POMIAN, 1984: 260) e até na época romana. Em Conimbriga encontrou-se um tijolo com o seguinte grafito: Ex Officin(a) Maelonis. Diarias rogatas solvi, "Da oficina de Melão. Satisfiz a quantidade de tijolos que me são exigidos diariamente" (ETIENNE e FABRE, 1976: 159). Desta inscrição parece poder deduzir-se que o proprietário da oficina tinha uma preocupação "capitalista" de aproveitar bem o tempo dos seus escravos ou empregados, exigindo-lhes determinada quantidade de tijolos por dia. 
Não podemos, pois, concordar com a afirmação de Shanks e Tilley de que "o tempo neutro e espacial... [corresponde à] cronometria capitalista" (1993: 125). Os autores fazem desta representação um conceito discursivo, historicamente situado; ora, ela não é um conceito, mas uma intuição transcendental do tempo puro. "Grandeza infinita dada, que precede e anticipa qualquer percepção possível, o tempo é, pois, esta forma vazia à espera dos acontecimentos que nele se podem produzir" (GRIMALDI, 1993: 29, itálico do autor). Não podemos admitir que o arqueólogo possa dispensar esta visão espacial, linear, do tempo, uma vez que ela é idealidade transcendental como afirmou Kant 0Crítica da razão pura § 6) ou estrutura ontológica como disse Barrett (1968: 373), identificando-a com a temporalidade ecstática heideggeriana, condição a priori da experiência e não ideia a posteriori derivada da experiência.

Temos, porém, de distinguir a intuição transcendental do tempo (concebido metaforicamente como rio de águas correntes ou como linha contínua), da experiência fenomenal do tempo, que é a experiência de uma sucessão de acontecimentos.

O tempo pode ser vivido como longo ou como breve: podemos ter a sensação de que o tempo não passa, de que passa devagar ou de que passa muito rápido. "Ao contrário do que disseram Hume e Condillac, o tempo não nos parece mais longo quando nele se passam mais coisas, mas quando nele se não passa nada; pelo contrário, é quando os acontecimentos se atropelam e se precipitam que ele nos parece mais curto..." (GRIMALDI, 1993: 20). No mesmo sentido se pronuncia Bachelard (1993: 37).

A intuição transcendental do tempo é a condição de possibilidade da experiência metafísica de um tempo vazio mas transcorrente, esse rio de que falava Heraclito, essa linha à qual o comparavam Kant e Bergson, ou ainda esse caminho deserto por onde todavia a qualquer momento podemos ver vir alguém, essa pauta vazia onde alguém pode vir a escrever as notas musicais, para usar agora as metáforas de Grimaldi (1993: 30-31). A experiência fenomenal do tempo é a de um tempo cheio, substancial, a de uma sucessão de factos. Shanks e Tilley, na tradição do empirismo inglês, atendem apenas à experiência fenomenal de devir e ignoram a experiência metafísica do tempo, que aquela mascara ou esconde, e que é todavia condição de possibilidade do fenómeno da espera: não poderíamos esperar o futuro se não tivéssemos, a priori, a intuição de que as coisas advêm umas atrás das outras. 
Não há arqueologia possível sem essa concepção linear do tempo, que é condição necessária para o estabelecimento do antes e do depois, das relações temporais dos factos, da sintaxe dos factos. Shanks e Tilley fazem do tempo linear uma construção histórica (capitalista), quando o que é construído são apenas as unidades de medida do tempo. Nós contamos por horas, dias, meses, anos, séculos; outros, os primitivos, não tinham horas nem anos: contavam talvez por dias, luas, gerações. O tempo linear é, para Shanks e Tilley, aquilo que ele realmente não é: uma abstracção. Como se nós chegássemos à concepção do tempo vazio a partir da experiência fenomenologica da sucessão e, abstraindo da sua concretude, isto é, dos factos que o preenchem, ficássemos com apenas um resíduo lógico, uma forma sem conteúdo.

O tempo linear é um tempo que se pode medir (em horas, dias, luas, anos, etc.), mas que não se pode apressar, nem retardar nem deter (SAnto Agostinho, Confissões XI, 23-24): o que pode decorrer mais depressa ou mais devagar, ou até deter-se, é o que se passa no tempo: esta trovoada, o arroteamento deste campo, a construção desta casa.

Para os homens da Pré-história, porém, não poderia o tempo deter-se ou ir mais devagar? Na literatura céltica ou na literatura popular mundial, que possivelmente conserva traços de um pensamento primitivo, são frequentes os exemplos em que um herói, transposto para um mundo sobrenatural em que julga ter permanecido apenas algumas horas ou alguns dias, observa, ao regressar ao mundo terreno, que se passaram anos ou séculos. Num conto russo (ORTEGA ORTEGA, 1993: 25), um herói entra no mundo encantado do fundo de um lago e aí encontra noiva; regressado ao mundo real, do qual julgava ter estado ausente apenas um dia, contente por poder apresentar a noiva aos pais, descobre que estes se tinham resignado, há três anos, a dá-lo como desaparecido: três anos haviam-lhe parecido um dia.

Deste exemplo, e de muitos outros similares, não nos parece, porém, que possa concluir-se que os primitivos admitiam a possibilidade de retardamento do tempo; simplesmente, consideravam que, "no mundo do Além, o tempo decorre num ritmo diferente do do mundo dos vivos" (ORTEGA ORTEGA, 1993: 25).

\section{O tempo cíclico, o tempo linear e o ritmo da mudança cultural}

O tempo representado como um caminho, agora deserto, mas onde alguém pode a certa altura surgir, e por onde esse alguém pode vir 
vindo ao nosso encontro, em passo mais rápido ou mais lento, é uma metáfora que nos permite compreender que a consciência é sempre espera do que vai ocorrer. Ora, há duas maneiras de o homem se posicionar perante o que há-de vir, perante o futuro: esperando-o na passividade, na pura disponibilidade de o acolher quando ele vier (como o agricultor espera que a seara amadureça para a ceifar) ou tomando a iniciativa, projectando o futuro e decidindo-se a fazê-lo passar ao presente. Esperar o futuro, instalado no presente, sem sair do lugar onde se está (como quem aguarda o autocarro) ou caminhar ao encontro do futuro (como eu posso caminhar ao encontro desse alguém que vem pelo caminho, em vez de simplesmente aguardar que ele chegue junto de mim) são duas atitudes fundamentais da consciência, distintas mas que se alternam no quotidiano. O eu é essa unidade orgânica, instável, do esperar passivo e do agir para concretizar um futuro que projecto, que preparo, que me mobiliza, me atrai e inquieta; mas o próprio esperar passivo não é necessariamente quietude, porque o eu que aguarda pode experimentar impaciência, curiosidade, excitação, numa gama de sentimentos cujo equilíbrio instável se vai alterando à medida que o esperado se vai perfilando, cada vez mais próximo de mim, isto é, do meu presente.

Se o homem se antecipa e age, se "ele é obrigado a decidir sobre si mesmo, sobre o seu poder ser, sobre o que ele deve ser e quer ser, sobre o que tem de ser e será" (PEREIRA, 1977: 49), o sentido da liberdade e da responsabilidade não exclui a expectação do que há-de vir sem que sejamos nós a decidi-lo: não somos nós a decidir a nossa morte, não é a mulher a decidir a hora das dores do parto, não é o cristão a decidir o momento da parusia do Senhor, que chegará inesperadamente, como o ladrão na noite, impondo ao crente uma atitude expectante e vigilante (S. PAUlo, $I^{a}$. Ep. aos Tessala 5, 2-3 e PereIRA, 1977: 51).

A vida é feita de esperas e ofensivas, de expectações e de projectos, de previsíveis e de inesperados, de repetições, de reiterações e de inovações e mudanças. Mas pode ter uma tonalidade dominante, que define a personalidade. E o que dizemos de um homem (que é mais activo ou passivo) pode dizer-se de uma sociedade. Não criaram os antropólogos a expressão cold societies para designar as que vivem predominantemente na reiteração do passado e na espera passiva do futuro, sem progresso técnico, e hot societies para exprimir as que são mais activas, as que inventam, as que progridem? As primeiras repre- 
sentam-se o tempo como predominantemente cíclico, reiterativo, e as segundas, como dominantemente linear, unidireccional.

Aqueles homens ou aquelas sociedades que vivem mais em contacto com a Natureza, e dependentes dela, são mais passivas, porque a Natureza, como disse Pascal CPensées, 121), recomeça sempre as mesmas coisas: esses têm uma experiência fenomenal do tempo cíclico. Perto da Natureza, o homem vive sob o signo do "eterno retorno do idêntico" (FERRAROTTI, 1990: 187) e instala-se na espera, como esses caçadores esquimós Nunamiut que estabelecem seus postos de caça na rota dos caribús e esperam 8 a 12 horas até que venha um animal (BINFORD, 1988:138).

A vivência na espera, a experiência do tempo cíclico, não é única: é apenas, para algumas sociedades, dominante. O distanciamento da Natureza, que corresponde a um afastamento do que é cíclico, traz consigo, como experiência fenomenal dominante, a da linearidade unidireccional do tempo e, como tonalidade dominante, a criatividade, quer no domínio do simbólico, quer no técnico, quer no das normas.

Mas a percepção do tempo cíclico e a percepção do tempo linear não se excluem: "as sociedades divergem pela maneira como enfatizam a percepção linear e/ou cíclica da duração" (HoWE, 1981: 223; duração tem, neste passo, o sentido de sucessão). O Cristianismo combina uma concepção cíclica (o ano litúrgico) com uma concepção linear (a espera escatologica do tempo).

O distanciamento da Natureza vai a par com a convocação dos homens a grupos cada vez mais vastos. Se, mesmo próximo da Natureza, o homem vive com outros homens, porque é de sua natureza ser sociável, "ser com", o seu distanciamento da Natureza intensifica as relações sociais, primeiro no seio da aldeia, depois, na cidade. Ora, não há sociedade sem distanciamento de uns aos outros, sem essa Abständigkeit herdeggeriana (HEIDEGGER, Etre et temps, § 27). Também a não há, é certo, sem aproximação de uns aos outros. Não existe distanciamento sem aproximação porque os homens se unem a outros homens para se oporem a terceiros: velhos unem-se a velhos e distanciam-se dos novos; homens unem-se a homens e distanciam-se das mulheres; guerreiros opõem-se a camponeses; sacerdotes, a leigos; tribo distancia-se de tribo. É próprio do eu procurar preservar a diferença, como é próprio do grupo procurar manifestar a ipseidade através de símbolos.

Este distanciamento conduz à diferenciação da cultura material, diferenciação que, como observam os arqueólogos contextualistas, não 
se pode explicar simplesmente como consequência de diferenças ambientais. Os objectos que se criam, que se inventam, não servem apenas para cumprir funções úteis, para satisfazer necessidades técnicas, mas também para simbolizar distâncias sociais. Os brincos das mulheres do Lago Baringo (Quénia) divergem de etnia para etnia (HODDER, 1982: 79-80) e servem para identificar a filiação étnica: vendo uma mulher, é possível, pelos seus brincos, dizer a que etnia pertence.

Ora, os objectos que simbolizam um grupo podem ser assimilados por outro grupo; nesse caso, não resta ao primeiro senão criar outros objectos que reponham a distância ou encontrar outras formas simbólicas de a reintroduzir. "Se um indivíduo ou um grupo pretende subir na hierarquia, pode procurar emular o grupo que se situa socialmente acima adoptando certos objectos ou estilos associados com o grupo superior. Se este deseja manter a sua posição superior, deve, ou tentar evitar isso, ou arranjar novos símbolos da sua diferenciação para manter o contraste anterior" (MILLER, 1982: 89).

Assim, a congregação dos homens em grupos cada vez mais vastos e interactuantes intensifica, pela necessidade do distanciamento recíproco, a produção de símbolos.

Por outro lado, aquilo que, numa análise superficial, pode parecer invenção de objectos úteis, pode ser, afinal, criação do simbólico. Como Binford demonstrou (1972: 26 s.), os primeiros artefactos de cobre dos índios da região dos Grandes Lagos, embora aparentemente úteis, não eram mais funcionais que os de pedra; na realidade, trata-se apenas de objectos sociotécnicos, insígnias de chefes, objectos que simbolizavam o poder.

Se o que parece artefacto útil é, por vezes, objecto simbólico, não podemos, porém, reduzir o útil ao simbólico. Há invenções técnicas que não são simbólicas. Parece difícil, se não impossível, reduzir o arado ou o moinho de vento a símbolos.

A evolução dos meios técnicos de produção, da organização social do trabalho, dos mecanismos de circulação de bens situam o homem num mundo de cultura cada vez mais distante da Natureza. Ora o mundo da cultura material é feito de coisas que têm uma origem, uma duração e um fim: este machado com que se abate uma árvore, esta casa que se habita. Estas coisas situam-se num tempo linear e não num tempo cíclico: não têm a natureza da árvore que ciclicamente dá flores e frutos, permanecendo a mesma, renovando-se a espaços ou intervalos regulares. A transição do mundo da Natureza para o mundo da cultura contribui para 
essa experiência fenomenal do tempo como linear e irreversível. Ao mesmo tempo, o homem experimenta-se como criador, como aquele por quem as coisas advêm à existência (tomando aqui "existência" no sentido pré-heideggeriano que lhe dava a ontologia tradicional).

A congregação dos homens em grupos cada vez mais vastos fá-los passar progressivamente da ascesis, que é submissão à ordem tradicional dos valores, que é conformidade, à hubris, que é insubmissão, contestação dos valores tradicionais (sobre os sentidos múltiplos de hubris vid. VERNANT, 1971,1: 13-41), ou à eris (disputa), que "faz crescer a guerra e as querelas" (HesíODO, Os trabalhos e os dias, 14). Num contexto conflituoso, as normas e os aparelhos tradicionais tornam-se insuficientes ou obsoletos, incapazes já de regerem a sociedade. Faz-se sentir a necessidade de criação de outras normas, outros aparelhos, que permitam resolver os noves problemas. $\mathrm{O}$ homem, que até então se regia por normas cuja origem situava no tempo mítico, torna-se criador de novas normas de que são responsáveis aqueles que são escolhidos para governar. Surgem, no quadro do conflito entre a aristocracia e o povo, e para repor a Dike (justiça), as leis de Sólon e a Lei das Doze Tábuas. Mas as normas, não já instituídas pelos deuses, deixam de ser imutáveis, aparecem como contingentes, como passíveis de revisão. E na experiência da criatividade, é no sentido, que o homem progressivamente adquire, da sua responsabilidade na criação de normas e de aparelhos, que se deve procurar a razão por que a mudança se acentua, se acelera; mais: a razão mesma pela qual há mudança. Se a representação do tempo como cíclico favorece a passividade e o fatalismo, a representação do tempo como linear, unidireccional e irrepetível é correlato da criatividade e da esperança.

Leach distingue ainda o tempo pendular. Com efeito, nalgumas sociedades primitivas, "não existe nenhum sentido de seguir sempre e sempre na mesma direcção, ou de girar, girar em uma mesma roda. Pelo contrário, o tempo é experimentado como algo descontínuo, uma repetição de oscilações entre opostos polares: dia e noite, inverno e verão, seca e cheia, velhice e juventude, vida e morte" (LEACH, 1974: 195); "com uma visão pendular do tempo, a sequência das coisas é descontínua; o tempo é uma sucessão de alternações e paradas" (LEACH, 1974: 206); "a noção de que o tempo é uma "descontinuidade de contrastes repetidos" é provavelmente a mais elementar e primitiva de todas as maneiras de encarar o tempo" (LEACH, 1974: 206; sobre o tempo pendular, vid. ainda BURMAN, 1981). 
Talvez esta visão pendular ou contrastiva do tempo se possa reduzir à visão cíclica: se o dia e a noite se alternam, o amanhecer de hoje representa a repetição do amanhecer de ontem. E talvez esta visão pendular implique ainda a visão linear: o dia, desde o amanhecer ao pôr do sol, segue irreversível desde o ponto de partida ao ponto de chegada.

O tempo cíclico, por seu lado, também não exclui o tempo linear, porque um ciclo, sendo a repetição de outro ciclo, ocorre noutro tempo. Como diz Howe (1981: 231, itálicos no original), "quando um ciclo termina, não regressa ao mesmo ponto temporal; regressa, e isso é muito diferente, ao mesmo ponto lógico". O amanhecer de hoje repete a madrugada de ontem, mas num outro ponto do tempo linear, unidireccional. Os ciclos podem representar-se como círculos desenhados ao longo de uma recta; os círculos vão-se repetindo, iguais uns aos outros, mas vão avançando na recta, da esquerda para a direita. Quer dizer: um ciclo começa naquele ponto temporal em que termina o ciclo anterior.

Como diz Adam, analisando a noção de tempo reversível ou cíclico de Giddens, "entre o inverno do ano passado e o deste ano, o recebimento do salário do mês passado e o deste mês, a lavagem da louça de ontem e a de hoje, o mundo mudou... O contexto é outro" (ADAM, 1994: 29).

\section{Conclusão}

"A vida social decorre em tempos múltiplos, sempre divergentes, com frequência contraditórios" (GURVITCH, 1986: 367, itálicos do autor). Vimos que há tempos objectivos, que o arqueólogo pode determinar, e tempos subjectivos, que ele não pode alcançar; um tempo da vida terrena e um tempo, mais lento, do mundo sobrenatural; um tempo das coisas e das acções, que é breve, e um tempo das normas, dos aparelhos e das paisagens, que, para quem os vive, podem ser imóveis, sendo, para quem os observa de fora e de longe, de evolução lenta; um tempo cíclico e um tempo linear unidireccional, podendo os dois tempos serem simultaneamente concebidos pelos mesmos sujeitos. E óbvio que o tempo fenomenal, o tempo substantivo, carregado de factos, não é observado pelo arqueólogo da mesma maneira que foi vivido pelos agentes: aquilo que chamámos o modo temporal de aparição dos factos aos agentes (antecipados, em tempo certo, atrasados) não pode ser apreendido, salvo, talvez, raras excepções. 
Se é legítimo contestar a universalidade de qualquer cronologia (Shanks e TILley, 1993: 125), não é possível dispensarmos a visão do tempo como linha contínua, unidireccional, mensurável, na qual posicionamos os acontecimentos: os factos arqueológicos não podem ser narrados senão num tempo linear.

\section{REFERÊNCIAS}

ADAM, Barbara, 1994: Time and social theory, Cambridge

ARISTóteles: Poética, (ed. trilingue por Valentín García Yebra), Madrid, 1974

BaChelard, Gaston, 1993: La dialectique de la durée, Paris

BaILEY, Douglass W., 1990: "The Irving house: signifying continuity", in SAMson, Ross (ed.); The social archaeology of houses, Edinburgh: 19-48

Bailey, G., 1981: "Concepts, time - scales and explanations in Economic Prehistory", in Sheridan, Alison e BaILey, Geoff (eds.), Economic Archaeology. Towards an integration of ecological and social approaches, Oxford

BaILEY, G.N., 1983: "Concepts of time in Quaternary pre-history", Annual Review of Anthropology, 12: 165-192

BARKER, Graeme, 1985: Prehistoric farming in Europe, Cambridge

Barrett, William, 1968: "The flow of time" in GaLe, Richard M. (ed), The Philosophy of Time. A collection of essays, Londres, 355-377

Berger, Peter L. e Luckmann, Thomas, 1976: A construção social da realidade, Petrópolis

Bergson, Henri, 1953: Matière et mémoire, Paris

BINFORD, Lewis R., 1972: An archaeological perspective, New York

BINFORD, Lewis R., 1988: En busca del pasado, Barcelona

Bogucky, Peter, 1988: Forest farmers and stockherders, Cambridge

Bourdieu, Pierre, 1990: The logic of practice, Londres

BRAUDEL, Fernand, 1983: O Mediterrâneo e o mundo mediterrânico na época de Filipe II, $1^{\circ}$. volume, Lisboa

BRAUDEL, Fernand, 1984: O Mediterrâneo e o mundo mediterrânico na época de Filipe II, $2^{\circ}$. volume, Lisboa

Burman, Rickie, 1981 : "Time and socioeconomic change on Simbo, Solomon Islands", Man, 16(2): 251-267

Carneiro, Robert L., 1979: "Tree felling with the stone ax: an experiment carried out among the Yanomamö Indians of southern Venezuela", in KraMer, Carol (ed.), Ethnoarchaeology. Implications of Ethnography for Archaeology, New York: $21-58$

Childe, Gordon, 1969: Para uma recuperação do passado. A interpretação dos dados arqueológicos, Lisboa

Cruz Cruz, Juan, 1993: Libertad en el tiempo. Ideas para una teoría de la historia, Pamplona

Conimbriga, 32-33 (1993-1994), 9-56 
CunlifFe, Barry, 1991: Iron Age communities in Britain, Londres

Dufrenne, Mikel, 1953: Phénoménologie de l'expérience esthétique, II, La perception esthétique, Paris

ElACURîA, Ignacio, 1991: Filosofía de la realidad histórica, Madrid

Eliade, Mircea, 1993: O mito do eterno retorno, Lisboa

ELIAS, Norbert, 1989: Sobre el tiempo, México

Etienne, R. e FABre, G. 1976: Fouilles de Conimbriga, II, Épigraphie et sculpture, Paris

FABIAN, Johannes, 1983: Time and the other. How Anthropology makes its object, New York

FerrarotTI, Franco, 1990: Time, memory and society, New York

FERRY, Jean-Marc, 1987: Habermas. L'éthique de la communication, Paris

GELL, Alfred, 1992: The anthropology of time. Cultural constructions of temporal maps and images, Oxford

GosDen, Christopher, 1994: Social being and time, Oxford

GrimaldI, Nicolas, 1993: Ontologie du temps. L'attente et la rupture, Paris

GuRVITCH, Georges, 1979: A vocação actual da Sociologia, I, Lisboa

GuRvitch, Georges, 1986: A vocação actual da Sociologia, II, Lisboa

Habermas, Jürgen, 1993: Técnica e ciência como “ideologia”, Lisboa

HeidegGer, Martin, 1994: Être et temps (trad. François Vezin), Paris

Hesíodo, Les travaux et les jours (éd. Paul Mazon), Paris, Les Belles Lettres, 1947

HodDER, Ian, 1982: Symbols in action. Ethnoarchaeological studies of material culture, Cambridge

HodDER, Ian (ed.), 1987: Archaeology as long-term history, Cambridge

HoDder, Ian, 1990: The domestication of Europe. Structure and contingency in Neolithic societies, Oxford

Howe, Leopold E.A., 1981: "The social determination of Knowledge: Maurice Bloch and Balinese time", Man, 16: 220-234

HuSSERL, Edmund, 1964: Leçons pour une phénoménologie de la conscience intime du temps, Paris

ISAMBERT, François, 1993: "Notes pour une phénoménologie de l'action”, in LADRIÈRE, Paul; PHaro, Patrick; QuÉRÉ, Louis (eds.), La théorie de l'action. Le sujet pratique en débat, Paris: 113-134

Kant, Immanuel, Crítica da razão pura (trad. Manuela Pinto dos Santos e Alexandre Fradique Morujão), Lisboa, 1985

KristianSEN, Kristian, 1984: "Ideology and material culture: an archaeological perspective", in SPRIGGS, Matthew (ed.), Marxist perspectives in archaeology, Cambridge: $12-100$

LEACH, E.R., 1974: Repensando a Antropologia, S. Paulo

LE GoFF, Jacques, 1979: "Na Idade Média: tempo da Igreja e tempo do mercador" in LE GoFf, Para um novo conceito da Idade Média. Tempo, trabalho e cultura no Ocidente, Lisboa

LÉvi-STrauSs, Claude, 1986: L'homme nu, Paris

Merleau-Ponty, M., 1945: Phénoménologie de la perception, Paris

Conimbriga, 32-33 (1993-1994), 9-56 
MiLLER, D., 1982: "Structures and strategies: an aspect of the relationship between social hierarchy and cultural change", in HodDER, Ian (ed.), Symbolic and structural archaeology, Cambridge: 89-98

Mosterín, Jesus, 1987: Racionalidad y acción humana, Madrid

MüLLER, Max, 1959: Expérience et histoire, Louvain

Ortega Ortega, José, 1993: “Contribución al estudio de la distorsión del tiempo en el mundo de ultratumba", Verdolay, 5: 25-33

Pascal, Pensées (Texte de l'édition Brunschvicg), Paris, Garnier, 1995

Pereira, Miguel Baptista, 1977: "Originalidade e novidade em Filosofia. A propósito da experiência e da história”, Biblos, 53: 1-113

Platão, Górgias (trad, de Manuel de Oliveira Pulquério in Série “Clássicos Gregos e Latinos", Lisboa, Verbo, 1973)

Pomian, Krzysztof, 1984: L'ordre du temps, Paris

Prichard, H.A., 1976: “Acto, volición y deseo”, in White, Alan R., 1976: 88-103

RENFREW, Colin, 1973: "Monuments, mobilization and social organization in Neolithic Wessex", in RENFREw (ed.), The explanation of culture change. Models in Prehistory, Londres, 539-558

Ricoeur, Paul, 1983: Temps et récit, I, Paris

RicoeUr, Paul, 1990: Do texto à acção, Lisboa

Santo Agostinho, Confissões (trad, de J. Oliveira Santos e A. Ambròsio de Pina), Porto, Livraria Apostolado da Imprensa, 1952

SARTRE, Jean-Paul, 1993: O Ser e o Nada, Lisboa

Shanks, Michael e TILLEY, Christopher, 1982: "Ideology, symbolic power and ritual communication: a reinterpretation of Neolithic mortuary practices", in HODDER (ed.), Symbolic and structural archaeology, Cambridge: 129-154

Shanks, Michael e Tilley, Christopher, 1993: Social theory and archaeology,

Cambridge

Tномаs, Julien, 1991: Rethinking the Neolithic, Cambridge

Toulmin, Stephen e GoODFIELD, 1967: The discovery of time, Harmondsworth

Vernant, Jean-Pierre, 1971: Mythe et pensée chez les Grecs, I e II, Paris

Weber, Max, 1983: A ética protestante e o espírito do capitalismo, Lisboa

White, Alan R., 1976: La filosofia de la acción, Mexico

Conimbriga, 32-33 (1993-1994), 9-56 